\title{
The Impact of Telecommunication Technologies on Competition in Services and Goods Markets: Empirical Evidence*
}

\section{Vahagn Jerbashian ${ }^{\dagger}$}

Departament de Teoria Econòmica and CREB, Universitat de Barcelona, 08034

Barcelona, Spain. (Corresponding author) vahagn.jerbashian@ub.edu

\section{Anna Kochanova}

Max Planck Institute for Research on Collective Goods, 53113 Bonn, Germany. kochanova@coll.mpg.de

February 19, 2016

\begin{abstract}
In this paper, we empirically show that a more intensive use and wider adoption of telecommunication technologies significantly increases the level of product market competition in services and goods markets. Our results are consistent with the view that the use of telecommunication technologies can lower the costs of entry and search. These findings are robust to various measures of competition and a wide range of specification checks.
\end{abstract}

Keywords: Telecommunication Technologies; Product Market Competition JEL classifications: L16; O33; O25

\footnotetext{
* We would like to thank two anonymous referees and the responsible editor, Peter Norman Sørensen, for valuable comments. Earlier drafts of this paper have benefited from comments by Michał Grajek, Jan Hanousek, Štěpán Jurajda, Lubomír Lízal, Pedro Pereira, Montserrat Vilalta-Bufi, Evangelia Vourvachaki, Krešimir Žigić, and the participants of various seminars. The authors gratefully acknowledge the financial support of Charles University through grant 584612. Vahagn Jerbashian gratefully acknowledges the financial support of the Spanish Ministry of Education and Science through grant ECO2012-34046 and the Generalitat of Catalonia through grant 2014SGR493.

${ }^{\dagger}$ Also affiliated with CERGE-EI, a joint workplace of Charles University in Prague and the Economics Institute of the Czech Academy of Sciences, Prague, Czech Republic.
} 


\section{Introduction}

"...[I]n most of the economy IT will help to increase competition.

Broadly speaking, the Internet reduces barriers to entry, because it is cheaper to set up a business online than to open a traditional shop or office. The Internet also makes it easier for consumers to compare prices. Both these factors increase competition."

The Economist, September 21, 2000

The internet is a type of telecommunication technology. Conjectures like this in The Economist indicate that there can be a positive relationship between the more intensive use and the wider adoption (hereafter, diffusion) of telecommunication technologies and competition in services and goods markets (for similar conjectures, see Leff, 1984; Freund and Weinhold, 2004; Czernich et al., 2011).

In this study, we empirically investigate the effect of the country-wide diffusion of telecommunication technologies on the competition in services and goods markets. In order to alleviate endogeneity concerns, we use a difference-in-differences framework in the spirit of Rajan and Zingales (1998). More specifically, we ask whether in countries with higher diffusion of telecommunication technologies the intensity of product market competition is different in the industries that depend more on these technologies compared to the industries that depend less. We use input-output matrices to measure the dependence on telecommunication technologies of industries. Our main measure of the diffusion of telecommunication technologies is the number of fixed-lines and mobile telephone subscribers per capita. It captures the adoption and use of telecommunications in the economy (e.g., Röller and Waverman, 2001). In turn, the main measure of product market competition is the price-cost margin. We use evidence from 21 European countries to establish our results.

Our results suggest that the diffusion of telecommunication technologies has a strong positive effect on the intensity of competition in services and goods markets. This finding is robust to various measures of competition, dependence, and diffusion. It is also robust to a wide range of specification checks and alternative identification assumptions, where 
we tackle further the endogeneity concerns. It supports conjectures such as in the quote above from The Economist.

To get a sense for the magnitude of the effect, consider the price-cost margin differential between industries at the 75 th percentile (Real Estate Activities) and at the 25th percentile (Manufacture of Other Transport Equipment) of the distribution of dependence on telecommunication technologies. Our estimates imply that this differential is higher by 0.02 in a country at the 25 th percentile (such as Estonia) of the distribution of telecommunication technologies diffusion than in a country at the 75 th percentile (such as France). This differential is economically sizable. For instance, it constitutes the 11 percent of the sample mean of the price-cost margin.

According to the standard theoretical inference, our results imply that the diffusion of telecommunication technologies increases allocative efficiency in the economy since it intensifies competition. Our results also imply that, through the same channel, the diffusion of telecommunication technologies can lead to productivity gains (Nickell, 1996; Syverson, 2004) and increase innovative activity (Blundell et al., 1999; Aghion et al., 2005; Griffith et al., 2010). ${ }^{1}$

This study contributes to the ongoing debate about the impact of telecommunication technologies, as well as of information and communication technologies (ICT), on economic performance. Macro-level empirical studies suggest that the diffusion of these technologies has a positive impact on the development level and growth (e.g., Röller and Waverman, 2001; Jorgenson and Vu, 2005). Micro-level empirical studies, in turn, find that the use of telecommunication technologies and ICT can reduce price dispersion and average prices (e.g., Brynjolfsson and Smith, 2000; Jensen, 2007; Brown and Goolsbee, 2002). There can be various drivers behind these results. For instance, the literature on the economics of ICT (e.g., Jorgenson et al., 2005) emphasises the productivity improvements/cost reductions that stem from the "direct" application of ICT (e.g., the switch from mail to e-mail). The literature on the economics of telecommunications, in addition,

\footnotetext{
${ }^{1}$ Aghion et al. (2005) find an inverted-U shape relationship between the innovative activity and the intensity of competition. Therefore, according to Aghion et al. (2005), our results imply higher innovative activity at least for low levels of competition.
} 
argues that the use of these technologies can improve access to information and reduce distortions and frictions in the markets (e.g., Leff, 1984; Jensen, 2007). ${ }^{2}$ Our empirical findings offer support for these conjectures. They imply that the diffusion of telecommunication technologies intensifies the competition in services and goods markets (i.e., reduces mark-ups). Meanwhile, given that the latter can matter for allocative and productive efficiency, our results suggest another driver behind the results of these macro- and micro-level empirical studies. In this respect, they contribute to the literature on general ICT and indicate that the economic benefits from a particular type of ICT, telecommunication technologies, may come not only from direct use, but also from intensified competition.

This inference can have implications for growth accounting and, specifically, for accounting the contribution of ICT to growth. For example, Oliner et al. (2008) argue that the contribution of ICT to labour productivity growth in the US industries has sharply declined recently (see also Acemoglu et al., 2014). The authors also offer evidence that increased competitive pressures explain a significant portion of recent growth. Our results highlight the possible role of ICT in increased competitive pressures in US industries and suggest that growth accounting exercises, which do not take into account this role, can understate the contribution of ICT to growth.

The results of this study can also be interesting for policymakers. They imply that policies that motivate higher use and wider adoption of telecommunication technologies can complement competition/antitrust policies.

Having mentioned what we identify in this study, it is also worth mentioning what we do not intend to identify. The diffusion of telecommunication technologies can reduce some of the costs of entry and search. However, it is ultimately the corresponding changes in firms' and consumers' behaviour that would affect the level of competition. Given the data we have, we neither can nor aim to identify exactly how those changes happen.

In addition to the literature on the economics of ICT and telecommunications, this

${ }^{2}$ Ellison and Ellison (2005) summarize this literature and conclude that modern communication technologies are unlikely to lead to "frictionless commerce." Our results suggest that these technologies reduce frictions in commerce, although we do not observe mark-ups falling to zero. 
paper is related to studies that examine the determinants of product market competition. Although competition seems to be an important engine of economic activity, to our best knowledge, there are very few such studies. There is evidence, for example, that railroad networks intensified competition in the US shipping industry in the 19th century (Holmes and Schmitz, 2001). There is also evidence that regulations can affect product market competition (e.g., Griffith et al., 2010; Fisman and Allende, 2010). Our paper is related to these studies to the extent that telecommunication technologies, similar to the railroad, are general purpose technologies. Moreover, according to our results, the policies that promote the diffusion of telecommunication technologies affect the intensity of competition.

The reminder of the paper is organized as follows. The next section describes the theoretical background, motivates the methodology and formally defines the objective of this study. The third section describes the data and their sources. The fourth section summarizes the results, and the last section concludes.

\section{Theoretical Background and Methodology}

\section{How Telecommunications Can Matter}

Primarily, we are interested in whether the diffusion of telecommunication technologies has a statistically and economically significant effect on product market competition. In this section, we briefly discuss how this can happen. We emphasise the channels which seem to be following from the literature in the most straightforward manner.

The entry and the potential entry of firms and entrepreneurs into a market can strengthen competition. The costs of entry involve, in particular, the costs of acquiring information about the market (Hurkens and Vulkan, 2001) and the costs of investments in infrastructure. It seems that it is a common thought in the literature that the use of telecommunication technologies can reduce the information acquisition costs (e.g., Leff, 1984; Röller and Waverman, 2001; Jensen, 2007). The reduction of the information acquisition costs can further help the entrants to find the best deals for infrastructure investments. This suggests that the diffusion of telecommunication technologies can reduce 
the costs of entry.

Arguably, the diffusion of telecommunication technologies can also reduce the firms' operating costs since, for example, it can improve information flow and management (e.g., Leff, 1984). This can lower the minimum profitable scale of firms and motivate entry.

Another plausible channel operates through the demand for services and goods. The diffusion of telecommunication technologies can reduce the search costs of consumers, entrants and (downstream) firms. This might increase the intensity of competition because of better arbitrage (e.g., Waterson, 2003; Pereira, 2005).

The arguments suggesting a positive relation between the diffusion of telecommunication technologies and the intensity of competition are in line with the conjectures of, for example, Freund and Weinhold (2004) and Czernich et al. (2011). ${ }^{3}$ However, they might not be fully evident. It can be argued as well that the diffusion of telecommunication technologies can help firms to gain market power. For example, it may help firms to increase product differentiation through the advertisement of products over the telecommunication networks, such as the internet. Moreover, lower information acquisition costs can help firms to learn about the demand and the general market environment. Therefore, they can help to increase price discrimination and product differentiation. Lower search costs can also hamper competition. For example, they can increase the likelihood of collusion, especially if the firms' collusion monitoring improves together with the decline of the consumers' search costs (Campbell et al., 2005).

The possible existence of countervailing channels suggests that it can also be insightful to learn the sign of the relationship between the diffusion of telecommunication technologies and product market competition. The diversity of these channels supports our focus on economy-wide diffusion of telecommunication technologies. For brevity, in the remainder of the paper we highlight the potential role of the diffusion of telecommunication technologies for firm entry since it might be easier to associate with firm behaviour and competition. Importantly, this does not obstruct our further theoretical inference.

\footnotetext{
${ }^{3}$ Freund and Weinhold (2004) hypothesise that the diffusion of telecommunication technologies and, in particular, of the internet can reduce the costs of entry. Further, they offer a stylized model, where the reduction of entry costs induces entry of firms and increases the intensity of competition.
} 


\section{Methodology}

In this paper, we identify the effect of the diffusion of telecommunication technologies on the competition in services and goods markets. Doing so is not straightforward, however. According to many theoretical models, the level of competition matters for resource allocation in the economy. This, in its turn, can affect the country-wide diffusion of telecommunication technologies creating a reverse link. Moreover, various (unobservable) country-level variables can affect competition and correlate with the diffusion of telecommunication technologies.

Nevertheless, there is an intuitive variation that can be used in order to alleviate these concerns. The effect of the diffusion of telecommunication technologies on the costs of entry would be different for industries that depend more heavily on these technologies compared to industries that depend less. Such variation can arise because the industries that depend more heavily on telecommunication technologies ceteris paribus would increase their demand for these technologies more due to that diffusion. In turn, in line with the arguments offered in Leff (1984) or Jensen (2007), the increased demand can result in more information about the industry. An observation that supports these arguments is that telecommunication technologies are used exactly for transmitting and disclosing information. A further supporting observation is that nowadays, for instance, computer producers and retailers seem to be more widely known than the core manufacturers, when the former use significantly more of these technologies. According to these arguments, the diffusion will alter the information acquisition costs disproportionately in industries that depend more heavily on telecommunication technologies. We offer a simple theoretical model that delivers predictions in line with this inference in the Online Appendix - Theoretical Model.

Our test looks for exactly such a disparity. We test whether in countries with higher diffusion of telecommunication technologies the level of product market competition is different in industries that depend more on these technologies compared to the industries that depend less. One of the advantages of this test is that we need not explain the country-level drivers behind the diffusion of telecommunication technologies, market or 
regulatory, and our inference would not depend on country-level models of competition. Our test also permits country and industry fixed effects, which can be important for capturing, for instance, institutional and regulatory differences and the variation in the fixed costs of entry into different industries.

To implement this test, our dependent variable is the level of product market competition in industry $i$ and country $c$ (averaged over the sample period). After controlling for industry and country fixed effects, in our empirical specification we should find that the coefficient on the interaction between the level of the diffusion of telecommunication technologies and industries' dependence on those technologies is different from zero. We also control for the initial share of an industry in a country in total output, which can capture potential convergence effects. For instance, it can correct for the possibility that the larger industries in a country experience lower entry rates (Klapper et al., 2006), which can affect the intensity of competition.

Our (baseline) empirical specification is then

$$
\begin{aligned}
\text { Competition }_{i, c}= & \alpha_{1, i}+\alpha_{2, c} \\
& +\alpha_{3} \cdot(\text { Industry } i \text { 's Dependence } \times \text { The Diffusion in Country } c) \\
& +\alpha_{4} \cdot \text { Industry } \text { Share }_{i, c}+\eta_{i, c},
\end{aligned}
$$

where $\alpha_{1}$ and $\alpha_{2}$ are the industry and country fixed effects, and $\eta_{i, c}$ is the error term. Our focus is on the coefficient of the interaction term, $\alpha_{3}$. This coefficient indicates whether countries with higher diffusion of telecommunication technologies have a different level of competition in industries that depend more on these technologies. It is positive (negative if we use an inverse measure for competition) if the diffusion of telecommunication technologies intensifies competition.

\section{Measures and Data}

We employ data for 21 European countries and focus on the period 1997-2006. We focus on these countries since they are fully covered by the OECD STAN and Amadeus databases, 
which we use to construct the measures of competition.

The use of data from a rather homogenous set of countries involves trade-offs. It can eliminate the influence of various unobservable factors on our inference, for example. However, at the same time it can weaken our inference from cross-country comparisons.

\section{Diffusion of Telecommunication Technologies}

Our main measure for the diffusion of telecommunication technologies is the number of fixed-lines and mobile telephone subscribers per capita in 1997 (Telecom Diffusion). ${ }^{45}$ This measure indicates the adoption and use of telecommunication technologies in the economy and is extensively used in that context. For example, Röller and Waverman (2001) use a similar measure to show that the diffusion of telecommunication technologies increases the rate of economic growth. Clearly, however, at least some part of the use measured in this manner will be hard to associate with the competition in services and goods markets. An example would be a tittle-tattle over the phone. Such a variation in the data can bias our results toward zero.

We obtain the data for this measure from the ITU and GMID databases. Table A1 in the Data Appendix offers basic statistics for the main variables, which are described in detail in Table A2. Tables A3.A10 in the Online Appendix - Further Results and Table A16 in the Online Appendix - Data offer correlations, basic statistics and descriptions of additional data.

\section{Dependence on Telecommunication Technologies}

In a country, a naive measure of an industry's dependence on telecommunication technologies (hereafter, telecom dependence) would be its share of expenditures on telecommunications out of total expenditures on intermediate inputs. The problem with this measure is that it reflects both the supply and the demand of those technologies when we

\footnotetext{
${ }^{4}$ The use of sample initial value helps us to alleviate further the reverse causality concerns.

${ }^{5}$ Adding also internet subscribers can lead to significant double counting since, for example, fixed-lines are used extensively for dial-up and DSL internet. Nevertheless, we have checked that our results remain qualitatively the same if we use the per capita number of internet subscribers as a measure of diffusion.
} 
need only the demand.

To alleviate this problem, as in the rest of the literature following Rajan and Zingales (1998), we identify the industries' dependence on telecommunication technologies from US data. Such a measure would be a valid proxy if the rank ordering of the expenditure share on telecommunications in US industries corresponds to the rank ordering of the technological dependence of the industries. We need as well that rank ordering to carry over to the rest of the countries in our sample. From another perspective, if our measure is noisy, our findings may only suffer from attenuation bias.

The data for the share of expenditures on telecommunications out of total expenditures on intermediate inputs in US industries are at the 2-digit industry level and come from the input-output tables of the Bureau of Economic Analysis (BEA). The original data are in NAICS 2007. We transform these data to ISIC rev. 3.1 (hereafter, ISIC), in order to align them with the rest of our data, and exclude the industries that are expected to have a large state involvement $\left(80,85,90\right.$ and 91 of ISIC). ${ }^{6}$ Further, we average these data over the period 1997-2006 and use the average as a measure for dependence. ${ }^{7}$

To gain confidence about the validity of our measure, we perform a simple ANOVA exercise on our data for the share of expenditures on telecommunications out of total expenditures on intermediate inputs in US industries. Industry-level variation accounts for $99.48 \%$ of the total variation, and time variation accounts for only $0.52 \%$. This provides support for the validity of our measure, suggesting that technological differences are the likely driver behind its variation. Further, we obtain the share of expenditures on telecommunications out of total expenditures on intermediate inputs in the industries from the countries in our sample from the OECD STAN database. These data have a structure similar to the 2-digit ISIC, though they are more aggregated and are available only for 1995, 2000 and 2005. We take the average of these three years and compute rank correlations between our dependence measure and these shares. The rank correlations are

${ }^{6}$ Our results are robust to their inclusion.

${ }^{7}$ Our results remain qualitatively the same when we use expenditures on telecommunications relative to output (the so-called "technical coefficients") and the coefficients of inverse Leontief matrix as measures of dependence (see Table A11 in the Online Appendix - Further Results). 
highly significant and range from 0.6 to 0.9 with a mean of 0.8 , which provides further support for the validity of our measure (see Table A8 in the Online Appendix - Further Results).

\section{Intensity of Competition and Industry Share}

We use five measures of product market competition averaged over the period 1997-2006. These measures are the most widely applied in the literature.

Following Nickell (1996) and Aghion et al. (2005), our primary (inverse) measure of product market competition is the price cost margin (PCM). Under the assumption of constant marginal cost, it is the empirical analogue of the Lerner index. Therefore, it tends to be the reference competition measure and is widely applied in the recent empirical work.

Using industry-level data, PCM is a weighted sum of Lerner indices in the industry across firms, where the weights are the market shares of the firms. In industry $i$, country $c$, and at time $t, \mathrm{PCM}$ is given by

$$
P C M_{i, c, t}=\frac{(\text { Revenue }- \text { Variable cost })_{i, c, t}}{\text { Revenue }_{i, c, t}}
$$

where the variable costs include labour compensation and expenditures on intermediate inputs. $^{8}$

Our second (inverse) measure for the intensity of competition is the profit elasticity (PE) introduced by Boone (2008). Profit elasticity captures the relation between profits and efficiency. This relation can be argued to become steeper as competition intensifies since in a more competitive environment the same percentage increase in costs reduces the profits more. In a given pair of industry and country and for all time periods, the PE is estimated using the following empirical specification:

\footnotetext{
${ }^{8}$ We follow Nickell (1996) and Oliner et al. (2008) while specifying PCM. In contrast, if we followed Aghion et al. (2005), we would have in the numerator net operating surplus minus financial costs. We do not prefer that measure since we have fewer data for it. Meanwhile, it is highly correlated with our measure $(\rho=0.7)$, and our results are qualitatively the same with it.
} 


$$
\ln \text { Profit }_{f, t}=\beta_{1, f}+\beta_{2, t}+\beta_{3, t} \ln \left(\frac{\text { Variable cost }}{\text { Revenue }}\right)_{f, t}+\eta_{f, t}
$$

where $f$ indexes firms, and $\eta_{f, t}$ is an error term. The PE in industry $i$, country $c$ and time $t$ is the estimated coefficient $\hat{\beta}_{3, i, c, t}$.

The third (inverse) measure is the Herfindahl index (HI), which is defined as the sum of the squared market shares of firms within an industry. Formally,

$$
H I_{i, c, t}=\sum_{f=1}^{N_{i, c, t}}\left(\frac{\text { Revenue }_{f, i, c, t}}{\sum_{f=1}^{N_{i, j, t}} \text { Revenue }_{f, i, c, t}}\right)^{2}
$$

where $N$ is the number of firms. The fourth one is the market share (MS) of the four largest firms in terms of revenues in each industry. Formally,

$$
M S_{i, c, t}=\frac{\sum_{\tilde{f}=1}^{4} \text { Revenue }_{\tilde{f}, i, c, t}}{\sum_{f=1}^{N_{i, c, t}} \text { Revenue }_{f, i, c, t}},
$$

where $\tilde{f}=1,2,3,4$ are the four largest firms in industry $i$ and country $c$ at time $t$.

The fifth measure of competition is the number of firms in each industry, $N_{i, c, t}$. It may seem to be the most simplistic and disputable. It may relatively firmly approximate the intensity of competition in situations close to symmetric equilibrium.

Even though these measures are widely applied, in certain cases they may not fully reflect the intensity of product market competition. For instance, when the competition intensifies from more aggressive conduct, some firms may leave the market. In such a situation, the Herfindahl index, being a concentration measure, can fail, suggesting that the intensity of competition has decreased. In the same situation, a similar problem can arise with the market share of the four largest firms when, for instance, one or several of the largest firms leave the market. ${ }^{9}$ Meanwhile, the price cost margin may fail in such a case when, for instance, inefficient firms leave the market. This would increase the weight of more efficient firms and, therefore, can increase the price cost margin (for further discussion, see Boone, 2008). Given its definition, this problem is not present,

\footnotetext{
${ }^{9}$ Another possible criticism that applies to concentration measures such as MS and HI is that these are more tied to the geographic and product boundaries of the market in which the firms operate.
} 
however, in the profit elasticity measure of competition. Nevertheless, given that all our measures have a somewhat different nature (i.e., can reflect different forces behind the intensity of competition), it seems reasonable to use them for robustness checks of our results. It is worth noting also that averaging over time would alleviate some of these concerns since we focus on a rather long-term level of competition.

We take the data for the price cost margin and the number of firms from the OECD STAN database and use the Amadeus database for the remaining measures of competition.

The Amadeus database has several features that need to be highlighted. First, in this database, there are virtually no data for the financial intermediation, insurance and pension funding industries. Therefore, our analysis for competition measures constructed using the Amadeus database excludes those industries. Second, this database does not cover the universe of firms and may not have a representative sample. For instance, according to Klapper et al. (2006), it tends to overstate the percentage of large firms. This can affect the competition measures identified from that database.

Our industry and country fixed effects are likely to reduce such biases; nevertheless, we perform several robustness checks. Klapper et al. (2006) compare the data from Amadeus with data from Eurostat in terms of the within-industry distribution of the size of the firms and keep only the industries and countries which are sufficiently close to the data from Eurostat. We have checked that all our results hold for the sample of countries and industries which were employed in Klapper et al. (2006). We have also calculated the price cost margin from firm-level data from the Amadeus database and checked that all our results hold for the sample of countries and industries where this measure is sufficiently close to its OECD STAN counterpart. ${ }^{10}$

Finally, the share of an industry in a country in total (business) output in 1997 is obtained from the OECD STAN database.

\footnotetext{
${ }^{10}$ Online Appendix - Data Cleaning describes further that database and offers our data cleaning procedure.
} 


\section{Results}

In column (1) of Table 1, we present our main result from the baseline specification (1), which we estimate using the least squares method. The dependent variable is our main (inverse) measure of intensity of product market competition, PCM, averaged over the period 1997-2006. Meanwhile, the interaction term consists of the logarithm of the diffusion measure in 1997, Telecom Diffusion, and the measure of dependence on telecommunication technologies, Telecom Dependence.

Table 1: The Main Result and the Results for Alternative Competition Measures

\begin{tabular}{lccccc}
\hline \hline & $(1)$ & $(2)$ & $(3)$ & $(4)$ & $(5)$ \\
& $\mathrm{PCM}$ & $\mathrm{PE}$ & $\mathrm{HI}$ & $\mathrm{MS}$ & $\log$ \\
\cline { 2 - 6 } Telecom Dependence & $-2.66^{* * *}$ & $-29.67^{* *}$ & $-1.58^{* * *}$ & $-1.88^{* * *}$ & $17.05^{* * *}$ \\
$\times$ Telecom Diffusion & $(0.37)$ & $(12.47)$ & $(0.54)$ & $(0.62)$ & $(3.92)$ \\
Industry Share & $0.69^{* * *}$ & $17.35^{* * *}$ & -0.25 & $-0.59^{*}$ & $10.55^{* * *}$ \\
& $(0.26)$ & $(4.81)$ & $(0.21)$ & $(0.34)$ & $(2.15)$ \\
\hline Observations & 902 & 844 & 876 & 876 & 818 \\
R2 & 0.72 & 0.52 & 0.59 & 0.73 & 0.93 \\
\hline \hline
\end{tabular}

Note: This table reports the results from the baseline specification (1) for all our measures of product market competition. See Table A2 in the Data Appendix for the definitions and sources of variables. All regressions include industry and country dummies and use the least squares estimation method. Robust (clustered) standard errors are in parentheses. $* * *$ indicates significance at the $1 \%$ level, ${ }^{* *}$ at the $5 \%$ level and $*$ at the $10 \%$ level.

The estimate of the coefficient on the interaction term is negative and significant at the 1\% level. Given that smaller values of PCM correspond to higher competition intensity, this indicates that in industries that depend more on telecommunication technologies, competition is more intensive in countries with higher diffusion of these technologies. The diffusion, therefore, has a positive effect on the intensity of competition in the services and goods markets. ${ }^{11}$

Since we have a difference-in-differences estimate, one way to compute the magnitude of our result is as follows. We take the countries that rank in the 25 th and 75 th per-

${ }^{11} \overline{\text { In the Online Appendix - Further Results, }}$, we also find that our results are stronger in countries with a higher quality of telecommunications infrastructure as measured by the broadband subscriptions. 
centiles of the distribution of Telecom Diffusion and compute the difference between the logarithms of the diffusion levels in these countries. The countries are Estonia (25th) and France (75th) in our sample. Further, we take the industries that rank in the 25th and 75th percentiles of the distribution of dependence on telecommunication technologies and compute the difference between the dependence levels. In our sample, these industries are Manufacture of Other Transport Equipment (25th) and Real Estate Activities (75th). Finally, we compute

$$
\hat{\alpha}_{3} \times \Delta \text { Telecom Dependence } \times \Delta \log (\text { Telecom Diffusion }),
$$

where $\Delta$ stands for the difference operator between the 75 th and 25 th percentiles. The computed number is -0.02 . This means that the difference in PCM (the intensity of competition) between Real Estate Activities and Manufacture of Other Transport Equipment is lower (higher) by 0.02 in France as compared to Estonia. This difference is sizeable and constitutes the $11 \%$ of the sample mean of PCM (0.19).

In an attempt to rule out other explanations for our main result, we conduct a range of robustness checks.

\section{Alternative Measures for Competition}

We estimate our baseline specification (1) for the remaining four competition measures in order to check whether our results are robust in terms of the competition measure. Columns (2)-(5) in Table 1 report the results where, all else equal, the dependent variable is correspondingly the profit elasticity, the Herfindahl index, the market share of the four largest firms, and the logarithm of the number of firms in an industry. All the estimates of the coefficients on the interaction terms have the expected signs and are significant at least at the $5 \%$ level.

We further report the estimation results exclusively for PCM. We have checked, however, that all our results stay qualitatively the same for the remaining measures of competition. 


\section{Alternative Measures for Diffusion and Dependence}

Our measure of the diffusion of telecommunication technologies may not fully reflect the use and the quality of these technologies, which can matter for the costs associated with information transmission. For a robustness check of our results, we also use the revenue of the telecommunications industry per capita as a measure of diffusion [Telecom Diffusion (Revenue)]. This measure can better account for the use and quality. However, from the between-country-comparison perspective, it may fail to reflect correctly the amount of telecommunication services produced since it could be higher, for example, simply because prices are higher. ${ }^{12}$ We obtain the data for the revenue of the telecommunications industry from the GMID and ITU databases.

Column (1) in Table 2 offers the results where we use the logarithm of the Telecom Diffusion (Revenue) in 1997. The estimated coefficient is negative and significant at the $1 \%$ level, which complements the result reported in column (1) of Table 1.

Further, our measure of dependence on telecommunication technologies might fail to identify the technological ranking of industries correctly. Although according to the rank correlation tests this is most likely not the case, we perform robustness checks.

For a robustness check, we employ the shares of expenditures on telecommunications out of total expenditures on intermediate inputs in industries in Japan. Similar to the US, this country has a well-developed ICT sector and a relatively high telecommunication technologies diffusion. At the same time, it tends to have a different industrial composition than the United States, which would be another type of robustness check.

The data for this measure were obtained from the input-output tables from the OECD STAN database. These data are slightly more aggregated than the data for our main measure and are only for 1995, 2000 and 2005. We average the share of the Japanese industries' expenditures on telecommunications over these three years and use it as a measure of dependence in our baseline specification (1).

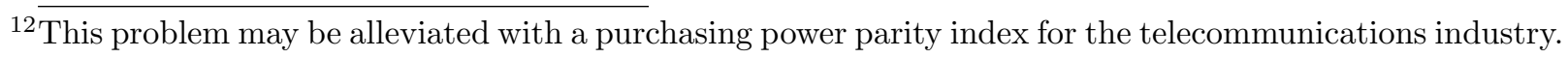
We are not aware of any good source of such data. Nevertheless, we have checked that our results are qualitatively not different if we adjust revenues by the price of a 3-minute local mobile phone call.
} 


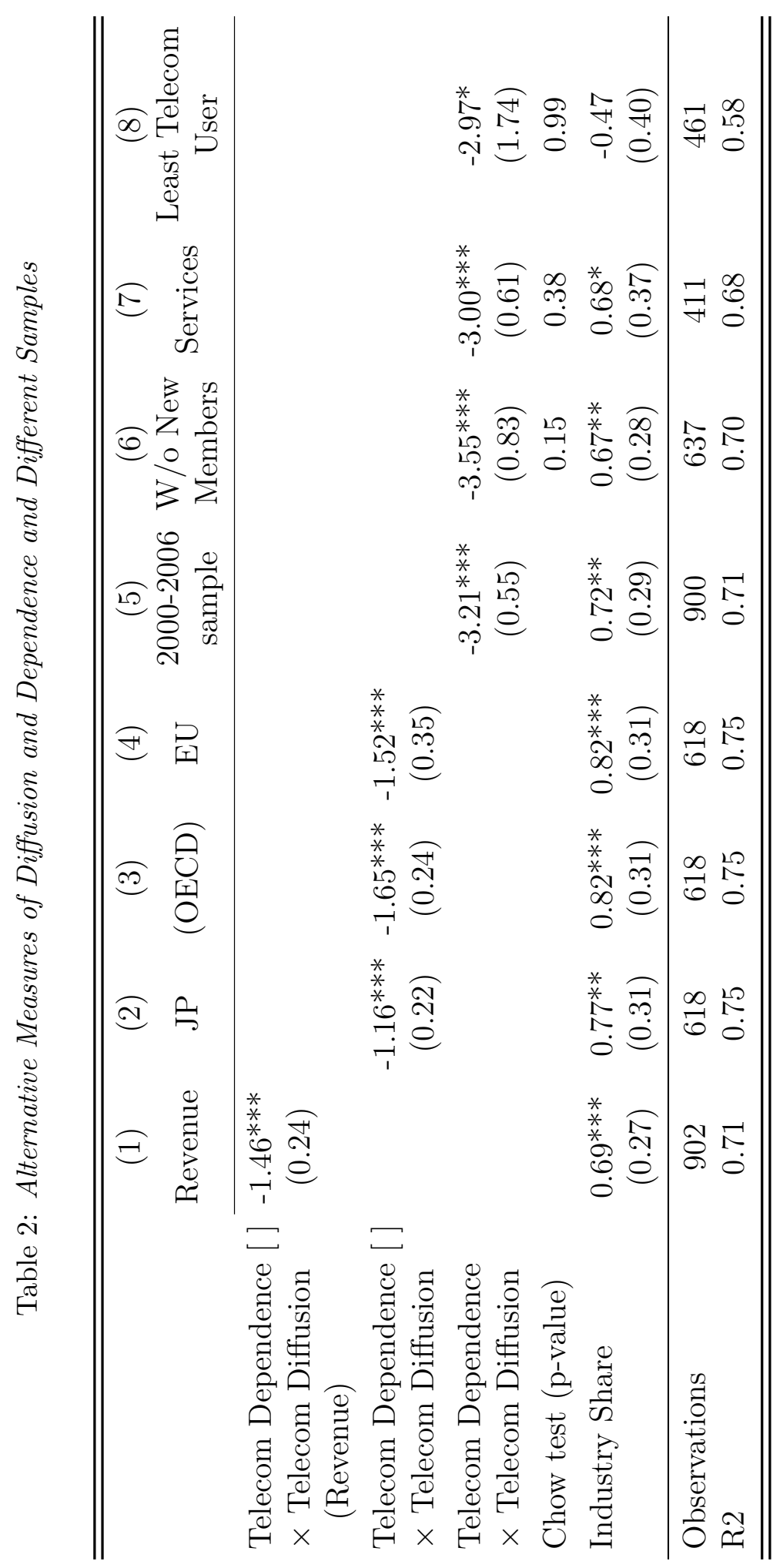

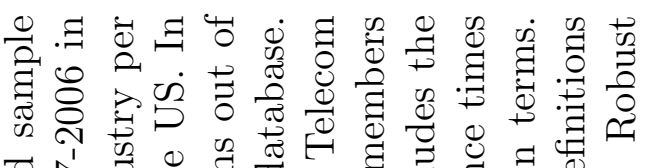

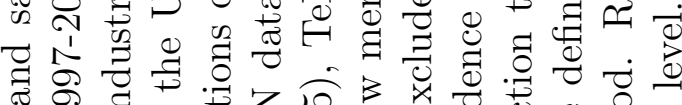

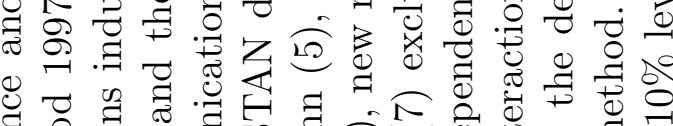

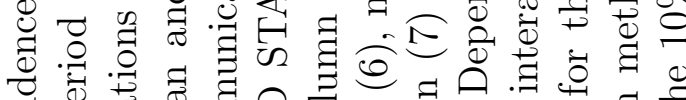

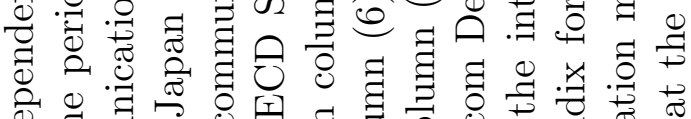

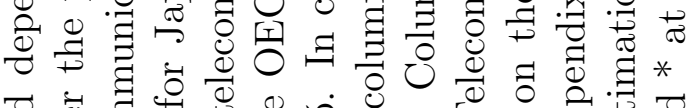
चี

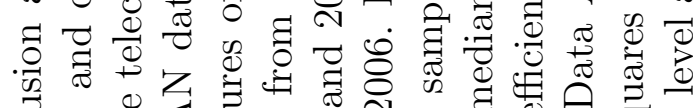

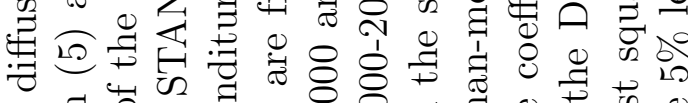

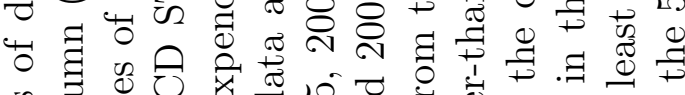

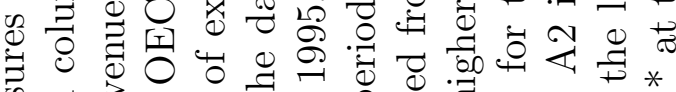

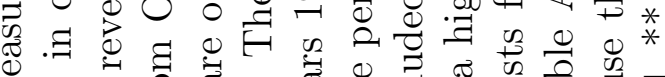

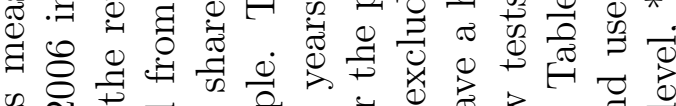

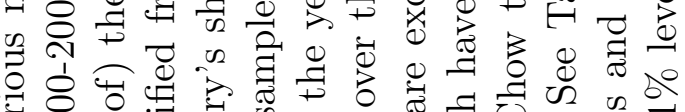

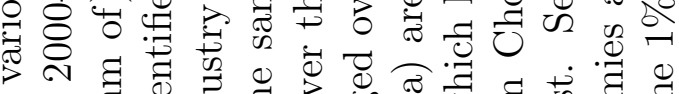

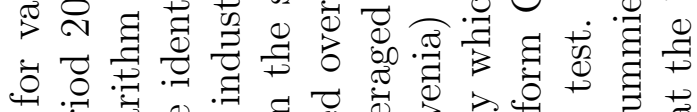

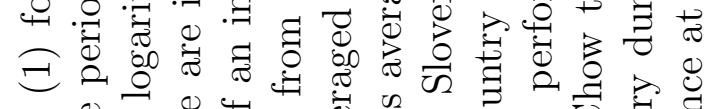

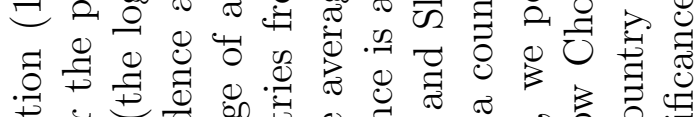

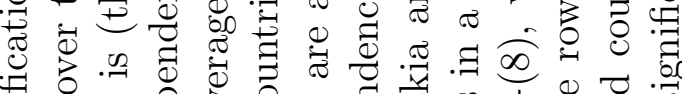
造 की

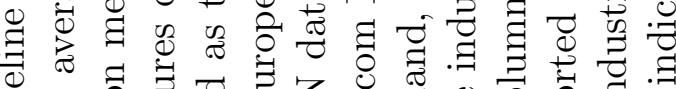

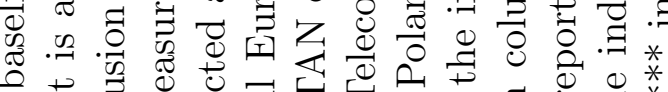

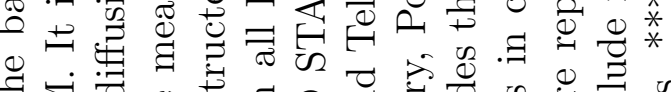

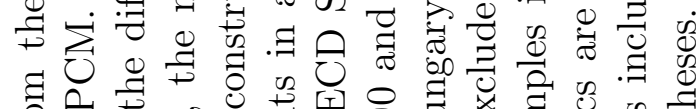

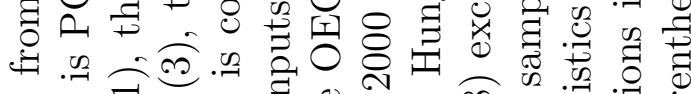

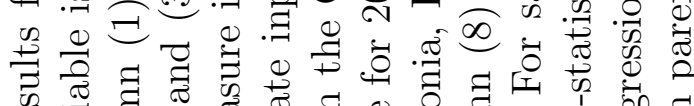

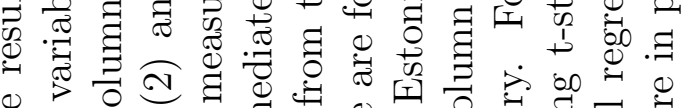

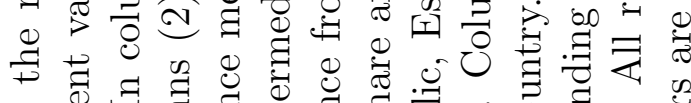

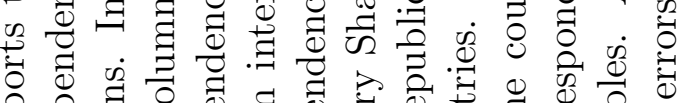

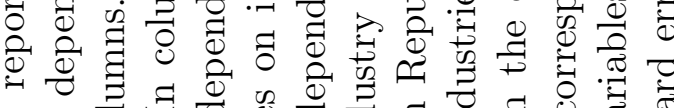

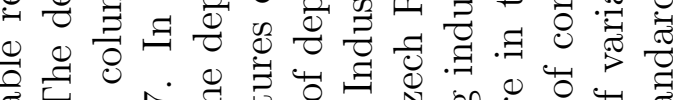

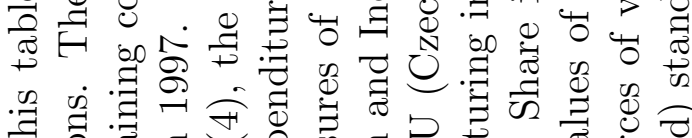

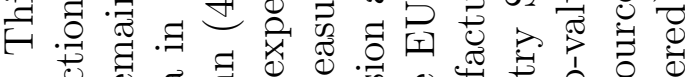
.

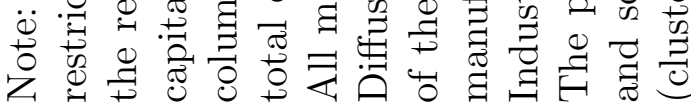


Column (2) in Table 2 reports the results. The estimate on the interaction term is again negative, which reaffirms our main result. However, it is somewhat smaller in absolute value. To check this result, we calculate a measure of dependence using data from the OECD STAN database on US industries. With this measure, the estimate of the coefficient on the interaction term is reported in Column (3) of Table 2. It is very close to the estimate that we obtain using the measure identified from the data for Japan. Moreover, it is quite close to the main result, although it implies a somewhat smaller effect. It is different, however, since the OECD STAN database has a higher industry aggregation. ${ }^{13}$

In Column (4) of Table 2, we use as a measure of dependence the country-time average of the expenditure share on telecommunications in industries in our sample of European countries. The estimate of the coefficient on the interaction term is not qualitatively different from the main one.

We further report exclusively the results for our main measures of diffusion and dependence. We have checked, however, that all our results are qualitatively the same for these alternatives.

\section{Non-parametric Estimator}

In our difference-in-differences estimation, we essentially divide the countries into high diffusion (HDIFF) and low diffusion (LDIFF) and the industries into high dependence (HDEP) and low dependence (LDEP). Abstracting from the control variables, our estimate is

$$
\text { [HDEP(HDIFF)-LDEP(HDIFF)]-[HDEP(LDIFF)-LDEP(LDIFF)], }
$$

which captures the average effect only. The effect that we compute with this nonparametric estimator is -0.03 . This result reassures us that the effect we have identified previously is generally present in all countries and industries.

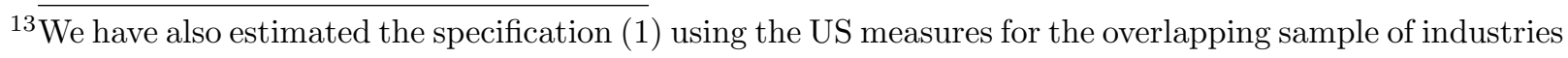
of the BEA and OECD STAN databases. The estimates are very close: $-1.80(0.30)$ and $-1.09(0.20)$, respectively.
} 


\section{Alternative Explanations: Do we capture integration processes?}

Further, we test whether our results are robust to various sample restrictions. First, we restrict our sample to 2000-2006 to check whether the market integration processes in the European Union affect our results. Column (5) in Table 2 reports the results from the baseline specification. The dependent variable is PCM and, together with the measure of telecom dependence, it is averaged over the period 2000-2006. The measure of telecommunication technologies diffusion and the industry share variable are from 2000 . The estimate of the coefficient on the interaction term is negative and highly significant. ${ }^{14}$ Its magnitude has increased in comparison with the main result, but not considerably. This suggests that the integration processes are not likely to be the drivers behind our results.

\section{Alternative Explanations: Are new members of the European Union different?}

The former transition countries (Czech Republic, Estonia, Hungary, Poland, Slovakia and Slovenia) which joined the European Union in 2004, can be different from the remaining countries in our sample. In these countries, the privatization process has resulted in the emergence of a large number of private firms (Klapper et al., 2006). Moreover, these countries have gone through large structural/industry changes. The latter can affect the intensity of competition, whereas the former can affect the patterns of telecommunication technologies use. We want to make sure that our results are not driven by these factors.

Column (6) in Table 2 reports the results when we exclude these countries from the sample. The estimate of the coefficient is not significantly different from the main estimate according to the Chow test.

\footnotetext{
${ }^{14}$ Our results are virtually the same if we consider the periods 1998-1999 and 1996-2005. Our results also do not change when we add to our specification the interaction between Telecom Dependence and the ratio of imports and exports to GDP, which can capture integration processes. Similarly, they do not change when we add the interaction between Telecom Diffusion and the ratio of industry-level imports and exports to output. (The data for imports and exports are from OECD STAN and OECD Stat.)
} 


\section{Alternative Explanations: Are the services industries different?}

The processes behind our results may be different in the services industries compared to the goods/manufacturing industries. This is because services products can be more easily marketed and delivered over telecommunication networks. Therefore, in line with the literature on electronic versus regular marketplaces, it might be reasonable to expect the role of the consumers' search costs to be different for the services industries. These costs can be important since they can affect the intensity of competition (Campbell et al., 2005; Pereira, 2005). Although theory does not have a clear-cut inference on the direction of the effect, empirical studies point out that lowering consumers' search costs increases the intensity of competition (e.g., Brown and Goolsbee, 2002).

Column (7) of Table 2 reports the results when we restrict the sample to the services industries. The estimate of the coefficient is essentially the same as our main estimate. In turn, the simple Chow test suggests that there is no significant difference between the services and the goods industries.

Alternative Explanations: Are the industries that use telecommunications the least any different?

We have also checked that our results are not qualitatively different from the main result for the industries that most likely affect the diffusion of telecommunication technologies the least. To identify such industries, we take the interaction between the variables Industry Share and Telecom Dependence and for a country take those industries that have a value lower than the median in that country.

Column (8) of Table 2 reports the results. The coefficient for the industries that have lower-than-median interaction between Telecom Dependence and Industry Share is essentially the same as our main result. This exercise suggests that our results are not likely to be driven by reverse causality. Nevertheless, we continue to explore such a possibility. 
Our inference would be incorrect if a third factor is responsible for the intensity of competition and is correlated with the interaction between dependence and diffusion measures. In this section, we attempt to rule out such an explanation of our results.

First, we try to alleviate further the reverse causality concerns and instrument the pre-determined level of the diffusion of telecommunication technologies. The set of instruments that we use consists of dummy variables for country groups: countries that joined the European Union in 2004, Scandinavian countries, and France-Germany. The first set of countries inherited (antiquated) telecommunications infrastructure from their socialist regimes. Scandinavian countries, in turn, were very effective in promoting universal access via state control and subsidies after deregulation. Meanwhile, France and Germany had the best access to mobile technologies through industry leaders such as La Compagnie Générale d'Électricité and Siemens. Column (1) in Table 3 reports the results. They are no different from our main results. ${ }^{15}$

Our country-group-level instrumental variables may not solve the endogeneity problem, however. It might be that they are correlated with some omitted variables and therefore do not satisfy the exclusion restrictions.

\section{Omitted Variables: Do we identify other costs of entry?}

According to, for example, Klapper et al. (2006), the country groups that comprise our instruments are quite different in terms of variables that matter for entry (and potential entry) and for the size distribution of firms and, thus, for the intensity of competition. Following Klapper et al. (2006) and Scarpetta et al. (2002), these variables are the bureaucratic costs of entry, product market regulation, financial development, the regulation of labour, property rights and human capital development (or the availability of qualified personnel). To the extent that the diffusion of telecommunication technologies is correlated with these variables (e.g., because it reflects the business environment), and

\footnotetext{
${ }^{15}$ Röller and Waverman (2001) use the waiting list for main lines per capita as an instrumental variable. Our results are robust to using this variable together with our instrumental variables and separately.
} 


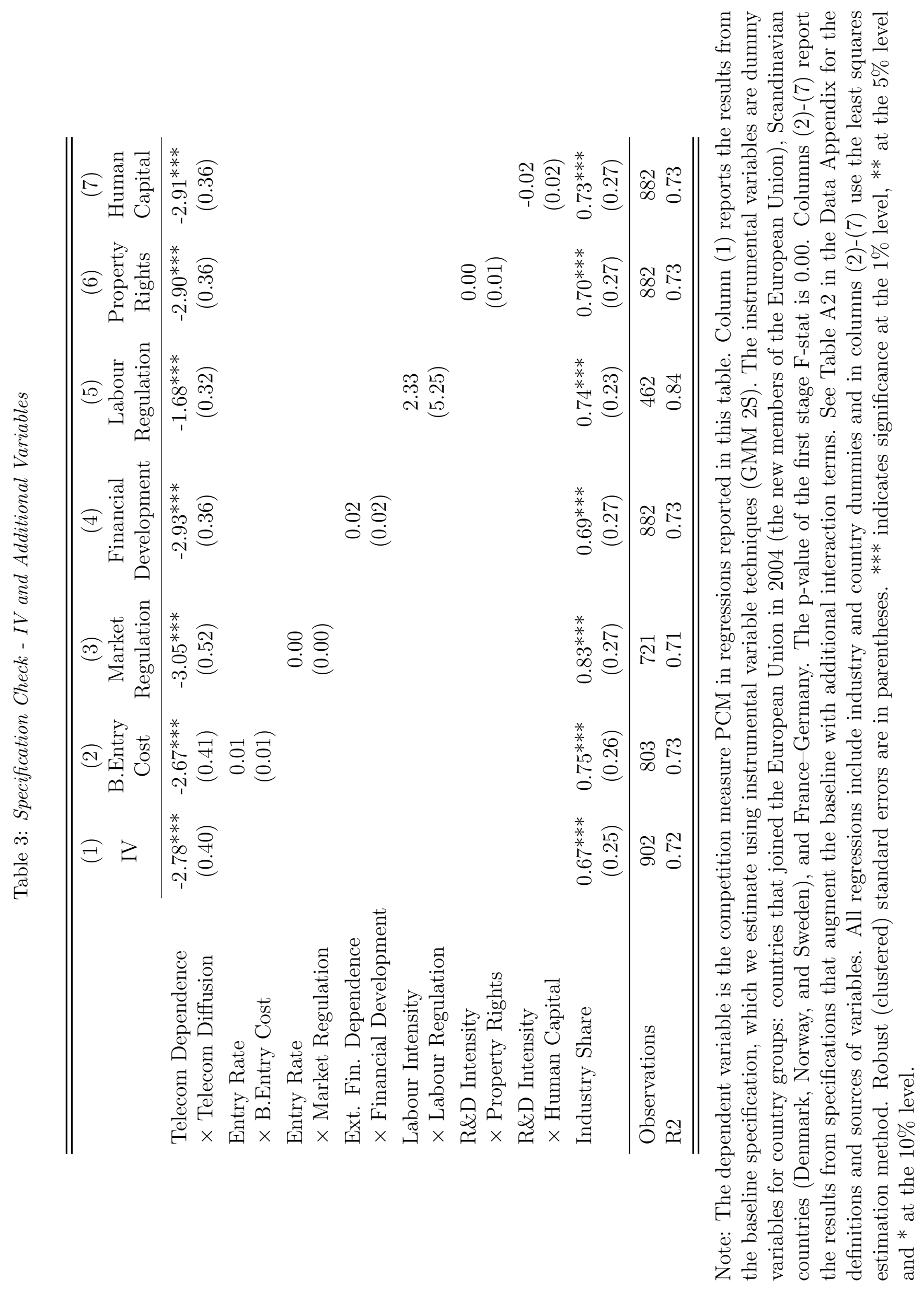


the rank of telecom dependence is correlated with the rank of the industries that are mostly affected by these variables, our inference would be incorrect.

We follow the literature to find measures for these country-level variables and to identify the ranking of industries according to the effect these variables should have on them (i.e., on the competition in those industries). We then include the interactions between these variables in the baseline specification.

We obtain the measure and the data for the bureaucratic costs of entry from Djankov et al. (2002). To measure the country-wide market regulation, we use the product market regulation indicator from OECD Stat. We measure the level of financial development as stock market capitalization over GDP and take the data from the WDI database. The measure and data for the regulation of labour are from Botero et al. (2004). Further, the property rights index constructed by the Heritage Foundation is used to proxy for property rights and their enforcement. Given availability, the data for these measures are for 1999, 1997, 1997, 1998 and 1997, respectively. Finally, we use the average years of schooling for the population older than 25 as a measure of human capital development. The data are for 1995, and we obtain them from the Barro-Lee tables, the World Bank. Table A2 in the Data Appendix offers detailed descriptions for these measures.

We also need the ranking of the industries according to the effect of these variables on them. The bureaucratic costs of entry, according to Klapper et al. (2006), have a higher impact on entry in "naturally" high-entry industries. It would be reasonable to expect that product market regulation matters in these industries in a similar way. Meanwhile, financial development, according to Rajan and Zingales (1998), has a higher impact on the creation of new establishments in industries that depend more on external finance. The strictness of labour regulation, in turn, could be expected to have a disproportionate impact on the industries that have high labour intensity. Further, property rights and human capital development would have a disproportionate impact on the industries that have high $R \& D$ intensity.

We use the measure and the data of Klapper et al. (2006) to identify the naturally high-entry industries. It is defined as the percentage of new corporations in an industry in 
the US, and it is averaged over the period 1998-1999 in that paper. We take the measures and the data for dependence on external finance and R\&D intensity from Bena and Ondko (2012). ${ }^{16}$ The first is defined as the industry median of the average of the ratio of capital expenditures minus cash flows from operations to capital expenditures over the period 1996-2005. Meanwhile, R\&D intensity is defined as the industry median of the ratio of averages of $R \& D$ expenditures to capital expenditures over the period 1996-2005. As a measure for labour intensity, we use the ratio of the number of employees to output in US industries averaged over the period 1997-2006. We take these data from the OECD STAN database.

In order to check whether any of these variables matter for our results, we create an interaction term and add it to the baseline specification (1). Columns (2)-(7) of Table 3 report the results. Clearly, the fact that we use data for the years 1999 and 1998 for bureaucratic costs of entry and market regulation can raise further endogeneity concerns. To alleviate these concerns, we have checked that our results are no different when we use data for competition, dependence and diffusion measures from the period 2000-2006, for example.

The coefficient on the interaction term between the measures of dependence and diffusion remains virtually the same in all cases. However, it somewhat decreases in absolute value when we insert the interaction between measures of labour regulation and labour intensity, column (5). This effect is neither significant nor driven by that interaction term. The coefficient on the interaction term in the baseline specification is virtually the same on the sub-sample where we have observations of the measures of labour regulation and intensity. In turn, the signs of the coefficients of the additional interaction terms tend to be intuitive, although the estimates are not significant. ${ }^{17}$

\footnotetext{
${ }^{16} \mathrm{We}$ are grateful to Peter Ondko for sharing his data with us.

${ }^{17}$ It might also be argued that the ranking of the industries according to their dependence on telecommunication technologies corresponds to the ranking of industries according to the effect these variables have on them. In Table A13 in the Online Appendix - Further Results, we explore this hypothesis. In that table, we also report the results when in addition to our main interaction term we include the interaction of Telecom Dependence with a market regulation indicator for the telecommunications industry.
} 
All these additional interaction terms, as well as our main interaction term, may proxy for the business/competitive environment in the country. Another rough way to proxy for that, together with the entrepreneurial culture in the country, is to include an interaction term of the Telecom Dependence variable with the average intensity of competition for the country. Column (1) of Table 4 reports the result when we include such an interaction term in our baseline specification. The coefficient of our main interest remains unaltered.

Table 4: Specification Check - Additional Variables

\begin{tabular}{lcccc}
\hline \hline & $(1)$ & $(2)$ & $(3)$ & $(4)$ \\
& $\begin{array}{c}\text { Business } \\
\text { Environment }\end{array}$ & $\begin{array}{c}\text { Growth } \\
\text { Potential }\end{array}$ & $\begin{array}{c}\text { Growth } \\
\text { Potential EU }\end{array}$ & $\begin{array}{c}\text { Average } \\
\text { Growth }\end{array}$ \\
\cline { 2 - 5 } Telecom Dependence & $-2.80^{* * *}$ & $-2.24^{* * *}$ & $-2.57^{* * *}$ & $-2.37^{* * *}$ \\
$\times$ Telecom Diffusion & $(0.39)$ & $(0.43)$ & $(0.37)$ & $(0.47)$ \\
Telecom Dependence & 13.06 & & & \\
$\times$ Business Environment & $(8.80)$ & & & \\
Growth Potential & & $-0.36^{* *}$ & & \\
$\times$ Telecom Diffusion & & $(0.16)$ & & \\
Growth Potential EU & & & $-0.43^{* * *}$ & \\
$\times$ Telecom Diffusion & & & & $0.12)$ \\
Average Growth & & & & $(0.04)$ \\
& & & & $0.93^{* * * *}$ \\
Industry Share & $0.69^{* * *}$ & $0.68^{* *}$ & $0.68^{* * *}$ & $(0.38)$ \\
\hline Observations & $(0.26)$ & $(0.27)$ & $(0.26)$ & 783 \\
R2 & 902 & 902 & 902 & 0.73 \\
\hline \hline
\end{tabular}

Note: This table reports the results from specifications that augment the baseline with additional interaction terms. The dependent variable is the competition measure PCM. See Table A2 in the Data Appendix for the definitions and sources of variables. All regressions include industry and country dummies and use the least squares estimation method. Robust (clustered) standard errors are in parentheses. $* * *$ indicates significance at the $1 \%$ level, ${ }^{* *}$ at the $5 \%$ level and ${ }^{*}$ at the $10 \%$ level.

Another concern is that it can be more valuable to obtain information about the products and prices in more competitive markets, and consumers might form their demand for telecommunications accordingly. The exercise offered above, together with our instrumental variable estimation results and results for industries which use telecommunications the least, suggests that this is likely not to be a major issue. Nonetheless, we also check 
that our results remain unaltered for industries which have lower than median level of competition in their countries, but these results are not reported.

Omitted Variables: Do we identify the growth potential of the industries?

It could also be that the measure of dependence on telecommunication technologies identifies the industries that have high growth potential. Meanwhile, such industries could depend on the availability of modern technologies, which might be proxied by the diffusion of telecommunication technologies, and face tougher competition due to attractiveness.

We follow Fisman and Love (2007) and use the growth rate of output of US industries averaged over the period 1998-2007 as a proxy for the growth potential of the industries. The data are from the Bureau of Economic Analysis. This proxy seems to be the most appropriate given the relatively low market imperfections in the United States. However, it could fail if there are important taste differences in the US compared to our sample countries. Therefore, we also use the growth rates of output of industries in the three most developed (measured by GDP per capita in 1997) European countries in our sample averaged over the countries and the 1998-2007 period.

We interact the proxies for growth potential with the measure of diffusion of telecommunication technologies and include the interactions in the baseline specification. Columns (2) and (3) of Table 4 report the results. The estimate of the coefficient on the interaction between Telecom Dependence and Telecom Diffusion stays virtually unaffected. The estimated coefficients on the interactions between Telecom Diffusion and the measures of growth potential are negative. This suggests that in countries where the diffusion of telecommunication technologies is higher, the competition is more intensive in industries with higher growth potential. An explanation for this can be that industries with high growth potential depend more on such (modern) technologies (see Table A10 in the Online Appendix - Further Results for the correlation between the measures of growth potential and dependence on telecommunication technologies). Therefore, a higher diffusion of telecommunication technologies reduces (potential) entry costs in these industries more than in low growth potential industries. 
As a final check, we also include in our baseline specification the growth rates of industries in the European countries from our sample averaged over the period 19982007. We report the result in column (4) of Table 4. Our main result stays virtually unaffected. It also stays unaffected if we include all these additional terms at once, but these results are not reported. (We offer results from further robustness check exercises in Tables A11.A14 in the Online Appendix - Further Results.)

\section{Conclusions}

In this study, we use industry-country-level data in order to identify the effect of the wider adoption and more intensive use (diffusion) of telecommunication technologies on the competition in services and goods markets. Taken together, our results offer robust evidence that the diffusion of telecommunication technologies significantly intensifies competition. It does so especially in the industries that depend more on these technologies.

According to the theory and empirical evidence, the intensity of product market competition matters for allocative and productive efficiency. Therefore, our results highlight a mechanism for how the use of a particular type of ICT, telecommunication technologies, can contribute to economic performance. This complements, for example, the productivity improvement mechanism that tends to be extensively emphasised in the literature. From this perspective, our results can have implications for accounting the contribution of ICT to growth in standard growth accounting frameworks, which do not take into account this effect on competition.

Our findings also suggest that the policies intended to promote the diffusion of telecommunication technologies can complement competition policies. 


\section{A Data Appendix}

Table A1: Summary Statistics

\begin{tabular}{|c|c|c|c|c|c|}
\hline Variable & Obs. & Mean & $\mathrm{SD}$ & Min. & Max. \\
\hline \multicolumn{6}{|l|}{ Country-level } \\
\hline B.Entry Cost & 20 & 0.19 & 0.20 & 0.01 & 0.86 \\
\hline Business Environment & 21 & 0.19 & 0.02 & 0.15 & 0.23 \\
\hline Financial Development & 21 & 0.28 & 0.23 & 0.02 & 0.79 \\
\hline Human Capital & 21 & 9.48 & 1.28 & 6.82 & 11.45 \\
\hline Labour Regulation & 20 & 0.61 & 0.15 & 0.28 & 0.81 \\
\hline Market Regulation & 18 & 2.25 & 0.65 & 1.07 & 3.97 \\
\hline Property Rights & 21 & 0.77 & 0.13 & 0.50 & 0.90 \\
\hline Telecom Diffusion & 21 & 0.61 & 0.23 & 0.22 & 1.06 \\
\hline Telecom Diffusion (Revenue) & 21 & 381.16 & 213.09 & 85.44 & 863.10 \\
\hline \multicolumn{6}{|l|}{ Industry-level } \\
\hline Entry Rate & 44 & 6.15 & 1.76 & 1.74 & 10.73 \\
\hline Ext. Fin. Dependence & 46 & 0.32 & 0.72 & -1.55 & 2.95 \\
\hline Growth Potential & 47 & 0.01 & 0.03 & -0.09 & 0.09 \\
\hline Growth Potential EU & 47 & 0.05 & 0.05 & -0.06 & 0.22 \\
\hline Labour Intensity & 24 & 0.01 & 0.00 & 0.00 & 0.02 \\
\hline R\&D Intensity & 46 & 0.70 & 1.16 & 0.00 & 4.17 \\
\hline Telecom Dependence & 47 & 0.01 & 0.02 & 0.00 & 0.06 \\
\hline Telecom Dependence EU & 30 & 0.02 & 0.02 & 0.00 & 0.08 \\
\hline Telecom Dependence JP & 30 & 0.02 & 0.02 & 0.00 & 0.09 \\
\hline Telecom Dependence (OECD) & 30 & 0.02 & 0.02 & 0.00 & 0.10 \\
\hline \multicolumn{6}{|l|}{ Industry-country-level } \\
\hline Average Growth & 788 & 0.05 & 0.07 & -0.61 & 0.48 \\
\hline $\mathrm{HI}$ & 928 & 0.14 & 0.17 & 0.00 & 1.00 \\
\hline Industry Share & 926 & 0.02 & 0.03 & 0.00 & 0.24 \\
\hline $\log \mathrm{N}$ & 863 & 7.24 & 2.63 & 1.39 & 13.49 \\
\hline MS & 928 & 0.45 & 0.27 & 0.02 & 1.00 \\
\hline PCM & 902 & 0.19 & 0.13 & 0.01 & 0.89 \\
\hline $\mathrm{PE}$ & 892 & -5.29 & 3.47 & -20.56 & -0.03 \\
\hline
\end{tabular}

Note: This table reports basic statistics for the key variables used in the paper. All variables and data sources are defined in detail in Table A2. 
Table A2: Definitions and Sources of Variables

\begin{tabular}{|c|c|}
\hline Variable Name & Definition and Source \\
\hline \multicolumn{2}{|l|}{ Country-level Variables } \\
\hline B.Entry Cost & $\begin{array}{l}\text { The bureaucratic cost of obtaining legal status to operate a } \\
\text { firm as the share of per capita GDP in 1999. Source: Djankov } \\
\text { et al. (2002). }\end{array}$ \\
\hline $\begin{array}{l}\text { Business Environ- } \\
\text { ment }\end{array}$ & $\begin{array}{l}\text { PCM averaged over industries in each country. The data } \\
\text { are for } 1997 \text {. Source: Authors' calculations using data from } \\
\text { OECD STAN. }\end{array}$ \\
\hline $\begin{array}{l}\text { Financial Develop- } \\
\text { ment }\end{array}$ & $\begin{array}{l}\text { The ratio of stock market capitalization to GDP in } 1997 . \\
\text { Source: WDI. }\end{array}$ \\
\hline Human Capital & $\begin{array}{l}\text { The average years of schooling of the population } 25 \text { years of } \\
\text { age or over in 1995. Source: Barro-Lee tables, World Bank. }\end{array}$ \\
\hline Labour Regulation & $\begin{array}{l}\text { Index of labour regulations in } 1997 \text {. It takes into account } \\
\text { job security, the conditions of employment and the provisions } \\
\text { in laws regarding alternative employment contracts. Source: } \\
\text { Botero et al. (2004). }\end{array}$ \\
\hline Market Regulation & $\begin{array}{l}\text { Product market regulation indicator in } 1998 \text {. It takes into } \\
\text { account the public control of business, bureaucratic barriers } \\
\text { to entrepreneurship, trade and investment. Source: OECD } \\
\text { Stat. }\end{array}$ \\
\hline Property Rights & $\begin{array}{l}\text { Property rights index in } 1997 \text {. It measures the protection of } \\
\text { private property in a country. Source: The Heritage Founda- } \\
\text { tion. }\end{array}$ \\
\hline
\end{tabular}


Table A2 - (Continued)

Variable Name Definition and Source

Telecom Diffusion The sum of fixed-lines and mobile telephone subscribers per capita in 1997. Source: Authors' calculations using data from ITU and GMID.

Telecom Diffusion The revenue of the telecommunications industry per capita (in (Revenue) 2000 US\$) in 1997. Source: Authors' calculations using data from ITU and GMID.

Industry-level Variables

Entry Rate The percentage of new corporations (firms that are not more than one year old) in US industries, averaged over the period 1998-1999. Source: Klapper et al. (2006) using Dun \& Bradstreet.

Ext. Fin. Depen- The median of the ratio of capital expenditures minus cash dence $\quad$ flow from operations over capital expenditures in US industries (where both are averaged over the period 1996-2005 for a firm). Source: Bena and Ondko (2012) using Compustat.

Growth Potential The annual growth rate of real output of US industries, averaged over the period 1998-2007. Source: Authors' calculations using data from BEA.

Growth Potential EU The annual growth rate of real output of industries from the three most developed European countries in terms of real GDP per capita in 1997, averaged over the countries and the period 1998-2007. Source: Authors' calculations using data from OECD STAN. 
Table A2 - (Continued)

Variable Name Definition and Source

Labour Intensity

The ratio of the number of employees to production (in $\$ 1000$ )

in US industries, averaged over the period 1997-2006. Source:

Authors' calculations using data from OECD STAN.

R\&D Intensity

The ratio of median $\mathrm{R} \& \mathrm{D}$ expenditures over median capital expenditures in US industries. Both components are averaged over the period 1996-2005. Source: Bena and Ondko (2012) using Compustat.

Telecom Dependence The share of (real) expenditures on telecommunications out of total expenditures on intermediate inputs in US industries, averaged over the period 1997-2006. Source: Authors' calculations using data from BEA, I-O tables.

Telecom Dependence The share of (real) expenditures on telecommunications out of EU total expenditures on intermediate inputs in industries in European countries from our sample, averaged over countries and the years 1995, 2000 and 2005. Source: Authors' calculations using data from OECD STAN, I-O tables.

Telecom Dependence The share of (real) expenditures on telecommunications out JP of total expenditures on intermediate inputs in industries in Japan, averaged over the years 1995, 2000 and 2005. Source: Authors' calculations using data from OECD STAN, I-O tables.

Telecom Dependence The share of (real) expenditures on telecommunications out (OECD) of total expenditures on intermediate inputs in US industries, averaged over the years 1995, 2000 and 2005. Source: Authors' calculations using data from OECD STAN, I-O tables. 
Table A2 - (Continued)

Variable Name Definition and Source

Industry-country-level Variables

Average Growth The annual growth rate of real output of industries from European countries in our sample, averaged over the period 19982007. Source: Authors' calculations using data from OECD STAN.

HI

Herfindahl index is computed as the sum of squared market shares of firms within an industry, averaged over the period 1997-2006. Source: Authors' calculations using data from Amadeus.

Industry Share The ratio of output in an industry in a country to the total (business) output in the country in 1997. Source: Authors' calculations using data from OECD STAN.

Least Telecom Users Dummy variable that takes value 1 for an industry-country pair if the interaction between Industry Share and Telecom Dependence is lower than the median in the country, and zero otherwise. Source: Authors' calculations using data from OECD STAN and BEA.

$\log \mathrm{N}$ The logarithm of the number of firms in an industry, averaged over the period 1997-2006. Source: OECD STAN.

MS Market share of the four largest firms in an industry, averaged over the period 1997-2006. Source: Authors' calculations using data from Amadeus. 
Table A2 - (Continued)

\begin{tabular}{ll}
\hline Variable Name & Definition and Source \\
\hline PCM & Price cost margin is computed as revenue (sales) minus in- \\
& termediate cost and labour costs divided by sales, averaged \\
& over the period 1997-2006. Source: Authors' calculations us- \\
& ing data from OECD STAN. \\
& Profit elasticity in an industry-country pair is the estimate of \\
& the coefficient $\beta_{3}$ in the empirical specification (3), averaged \\
& over 1997-2006. Source: Authors' calculations using data from \\
& Amadeus. \\
\hline \hline
\end{tabular}

Country Sample:

Austria, Belgium, Czech Republic ${ }^{1}$, Denmark ${ }^{2}$, Estonia ${ }^{1}$, Finland, France, Germany, Greece, Hungary ${ }^{1}$, Ireland, Italy, Netherlands, Norway ${ }^{2}$, Poland ${ }^{1}$, Portugal, Slovakia ${ }^{1}$, Slovenia ${ }^{1}$, Spain, Sweden ${ }^{2}$ and UK. ( ${ }^{1}$ new members of the EU; ${ }^{2}$ three most developed European countries in terms of GDP per capita in 1997.)

Industry Sample (ISIC rev. 3.1):

10, 11, 13-36, 40, 41, 45, 50-52, 55, 60-63, 65-67, 70-74, 92 and 93. (Industries 65-67 are not in the sample for competition measures constructed using Amadeus data. In OECD STAN data, industries 10-14, 15-16, 17-19, 21-22, 36-37, 40-41, 50-52, 60-63 and 65-67 are merged. Further, these data do not contain industries 92 and 93.) 


\section{References}

Acemoglu, D., D. Autor, D. Dorn, G. Hanson, and B. Price (2014). Return of the Solow paradox? IT, productivity and employment in U.S. manufacturing. American Economic Review: Papers 83 Proceedings 104 (5), 394-399.

Aghion, P., N. Bloom, R. Blundell, R. Griffith, and P. Howitt (2005). Competition and innovation: An inverted-U relationship. Quarterly Journal of Economics 120(2), 701728.

Bena, J. and P. Ondko (2012). Financial development and the allocation of external finance. Journal of Empirical Finance 19(1), 1-25.

Blundell, R., R. Griffith, and J. M. van Reenen (1999). Market share, market value and innovation in a panel of British manufacturing firms. Review of Economic Studies 66(3), $529-554$.

Boone, J. (2008). A new way to measure competition. Economic Journal 118(531), $1245-1261$.

Botero, J. C., S. Djankov, R. La Porta, F. Lopez-de-Silanes, and A. Shleifer (2004). The regulation of labor. Quarterly Journal of Economics 119(4), 1339-1382.

Brown, J. R. and A. Goolsbee (2002). Does the Internet make markets more competitive? Evidence from the life insurance industry. Journal of Political Economy 110(3), 481507.

Brynjolfsson, E. and M. D. Smith (2000). Frictionless commerce? A comparison of internet and conventional retailers. Management Science 46(4), 563-585.

Campbell, C., G. Ray, and W. A. Muhanna (2005). Search and collusion in electronic markets. Management Science 51(3), 497-507.

Czernich, N., O. Falck, T. Kretschmer, and L. Woessmann (2011). Broadband infrastructure and economic growth. Economic Journal 121(552), 505-532.

Djankov, S., R. La Porta, F. Lopez-de-Silanes, and A. Shleifer (2002). The regulation of entry. Quarterly Journal of Economics 117(1), 1-35.

Ellison, G. and S. F. Ellison (2005). Lessons about markets from the Internet. Journal of Economic Perspectives 19(2), 139-158.

Fisman, R. and V. S. Allende (2010). Regulation of entry and the distortion of industrial organization. Journal of Applied Economics 13(1), 91-111.

Fisman, R. and I. Love (2007). Financial dependence and growth revisited. The Journal of the European Economic Association 5(2-3), 470-479.

Freund, C. L. and D. Weinhold (2004). The effect of the Internet on international trade. Journal of International Economics 62(1), 171-189.

Griffith, R., R. Harrison, and H. Simpson (2010). Product market reform and innovation in the EU. Scandinavian Journal of Economics 112(2), 389-415.

Holmes, T. J. and J. A. Schmitz (2001). Competition at work: Railroads vs. monopoly 
in the U.S. shipping industry. Federal Reserve Bank of Minneapolis Quarterly Review 25(2), 3-29.

Hurkens, S. and N. Vulkan (2001). Information acquisition and entry. Journal of Economic Behavior \&6 Organization 44(4), 467-479.

Jensen, R. (2007). The digital provide: Information (technology), market performance, and welfare in the South Indian fisheries sectors. Quarterly Journal of Economics 122(3), 879-924.

Jorgenson, D. W., M. S. Ho, and K. J. Stiroh (2005). Information technology and the American growth resurgence. Cambridge, MA: MIT Press.

Jorgenson, D. W. and K. Vu (2005). Information technology and the world economy. Scandinavian Journal of Economics 107(4), 631-650.

Klapper, L., L. Laeven, and R. G. Rajan (2006). Entry regulation as a barrier to entrepreneurship. Journal of Financial Economics 82(3), 591-629.

Leff, N. H. (1984). Externalities, information costs, and social benefit-cost analysis for economic development: An example from telecommunications. Economic Development and Cultural Change 32(2), 255-276.

Nickell, S. J. (1996). Competition and corporate performance. Journal of Political Economy $104(4), 724-746$.

Oliner, S. D., D. E. Sichel, and K. J. Stiroh (2008). Explaining a productive decade. Journal of Policy Modeling 30(4), 633-673.

Pereira, P. (2005). Do lower search costs reduce prices and price dispersion? Information Economics and Policy 17(1), 61-72.

Rajan, R. G. and L. Zingales (1998). Financial dependence and growth. American Economic Review 88(3), 559-586.

Röller, L.-H. and L. Waverman (2001). Telecommunications infrastructure and economic development: A simultaneous approach. American Economic Review 91(4), 909-923.

Scarpetta, S., P. Hemmings, T. Tressel, and J. Woo (2002). The role of policy and institutions for productivity and firm dynamics: Evidence from micro and industry data. OECD Economics Department Working Papers, wp. 329.

Schneider, F. (2002). Size and measurement of the informal economy in 110 countries around the world. Paper presented at the Workshop of Australian National Tax Centre, ANU. Canberra, Australia. July 17, 2002.

Syverson, C. (2004). Market structure and productivity: A concrete example. Journal of Political Economy 112(6), 1181-1222.

Waterson, M. (2003). The role of consumers in competition and competition policy. International Journal of Industrial Organization 21(2), 129-150. 


\section{Online Appendix to "The Impact of \\ Telecommunication Technologies on Competition \\ in Services And Goods Markets: Empirical \\ EVIDENCE"}

Vahagn Jerbashian* $\quad$ Anna Kochanova $^{\dagger}$

\section{B Online Appendix - Theoretical Model}

In this section, we present a minimalist deterministic model that delivers predictions in line with our inference. There are two intermediate goods industries which produce differentiated goods $\left\{x_{1}\right\}$ and $\left\{x_{2}\right\}$. Final goods $(Y)$ are produced with a Cobb-Douglas production technology:

$$
Y=\lambda_{Y} X_{1}^{\sigma_{1}} X_{2}^{\sigma_{2}}
$$

where $\sigma_{1}, \sigma_{2}>0$ and $\sigma_{1}+\sigma_{2}=1, \lambda_{Y}>0$, and $X_{1}$ and $X_{2}$ are CES aggregates of the intermediate goods,

$$
X_{i}=\left(\sum_{f=1}^{N_{i}} x_{i, f}^{\frac{\varepsilon_{i}-1}{\varepsilon_{i}}}\right)^{\frac{\varepsilon_{i}}{\varepsilon_{i}-1}}, i=1,2 .
$$

Here $i$ indexes the industries, $N$ stands for the number of firms, $f$ indexes the firms, and $\varepsilon>1$ is the elasticity of substitution between the products of the firms in these industries.

* Departament de Teoria Econòmica and CREB, Universitat de Barcelona, and CERGE-EI.

Address (corresponding author): University of Barcelona, Avenue Diagonal 696, 08034 Barcelona, Spain. Phone: +34934034890. E-mail: vahagn.jerbashian@ub.edu

${ }^{\dagger}$ Max Planck Institute for Research on Collective Goods, Bonn, Germany.

CERGE-EI is a joint workplace of the Center for Economic Research and Graduate Education, Charles University in Prague, and the Economics Institute of Academy of Sciences of the Czech Republic. 
Normalizing aggregate demand to 1 and taking final goods as the numeraire, it follows that the demand for the product of firm $j \in\left\{1, \ldots, N_{i}\right\}$ in industry $i \in\{1,2\}, x_{i, j}$, is

$$
p_{x_{i, j}} x_{i, j}=\sigma_{i} \frac{x_{i, j}^{\frac{\varepsilon_{i}-1}{\varepsilon_{i}}}}{\sum_{f=1}^{N_{i}} x_{i, f}^{\frac{\varepsilon_{i}-1}{\varepsilon_{i}}}},
$$

where $p_{x_{i, j}}$ is the price of $x_{i, j}$.

Further, $x_{1}$ and $x_{2}$ are produced using telecommunication technologies $(T)$ and some other good $(L)$ with Cobb-Douglas production technologies,

$$
x_{i}=\lambda_{i} T_{i}^{\gamma_{i}} L_{i}^{1-\gamma_{i}}
$$

where $\lambda_{i}>0$ and $\gamma_{i} \in(0,1)$ for $i \in\{1,2\}$. The parameters $\gamma_{1}$ and $\gamma_{2}$ are the output elasticities of the telecommunication technologies input in industry 1 and 2, respectively. In this sense, they measure the dependence on this input. We assume that $\gamma_{1}>\gamma_{2}$ : Industry 1 depends on telecommunication technologies more than industry 2 .

For simplicity, we assume that firms live for one period. Meanwhile, the entrants pay a fixed cost $F_{i}$ for entry into the respective industry, and there is free entry into the industries (where $F_{i}<\sigma_{i} / \varepsilon_{i}$ for $i=1,2$ since aggregate demand is equal to 1 ). In order to cover the costs of entry, these firms set prices and engage in quantity (Cournot) competition. In an industry, each firm internalizes its effect on the demand for the goods of the remaining firms in the industry.

The problem of a firm $j \in\left\{1, \ldots, N_{i}\right\}$ in industry $i \in\{1,2\}$ is given by

$$
\begin{aligned}
& \pi_{i, j}=\max _{T_{i, j}, L_{i, j}}\left\{p_{x_{i, j}} x_{i, j}-p_{T} T_{i, j}-p_{L} L_{i, j}-F_{i}\right\} \\
& \text { s.t. }
\end{aligned}
$$

where $p_{T}$ and $p_{L}$ are the prices of $T$ and $L$. 
It follows from firm $j$ 's problem that its demands for $T$ and $L$ are given by

$$
\begin{aligned}
& p_{T}=p_{x_{i, j}}\left(1-\frac{1}{e_{i, j}}\right) \frac{\partial x_{i, j}}{\partial T_{i, j}} \\
& p_{L}=p_{x_{i, j}}\left(1-\frac{1}{e_{i, j}}\right) \frac{\partial x_{i, j}}{\partial L_{i, j}}
\end{aligned}
$$

where $e_{i, j}$ is firm $j$ 's perceived elasticity of substitution between goods in its industry:

$$
e_{i, j}=\varepsilon_{i}\left[1+\left(\varepsilon_{i}-1\right) \frac{x_{i, j}^{\frac{\varepsilon_{i}-1}{\varepsilon i}}}{\sum_{f=1}^{N_{i}} x_{i, f}^{\frac{\varepsilon_{i}-1}{\varepsilon_{i}}}}\right]^{-1} .
$$

In this framework, competitive pressure in an industry can be expressed in terms of the Lerner index $(L I)$. For firm $j$ from industry $i$ this index can be derived from (6), (8) and (9). It is given by

$$
L I_{i, j}=\frac{1}{e_{i, j}}
$$

Ceteris paribus, in an industry, it declines with actual elasticity of substitution $\varepsilon$ and the number of firms $N$.

Hereafter we assume that symmetric equilibrium holds in each of the industries. The perceived elasticity of substitution can be then rewritten as

$$
e_{i}=\frac{\varepsilon_{i}}{1+\frac{\varepsilon_{i}-1}{N_{i}}}
$$

In turn, the demands for $T$ and $L$ in each industry can be written as

$$
\begin{aligned}
N_{i} p_{T} T_{i} & =\sigma_{i} \gamma_{i}\left(1-\frac{1}{e_{i}}\right) \\
N_{i} p_{L} L_{i} & =\sigma_{i}\left(1-\gamma_{i}\right)\left(1-\frac{1}{e_{i}}\right) .
\end{aligned}
$$

Given that there is free entry, the number of firms in each industry is determined by a zero profit condition $\pi_{i}=0$. Using (5), (7), (10) and (11), it can be easily shown that 
this condition is equivalent to

$$
\sigma_{i} \frac{1}{N_{i}}=\sigma_{i}\left(1-\frac{1}{e_{i}}\right) \frac{1}{N_{i}}+F_{i}
$$

Therefore, the number of firms in each industry is

$$
N_{i}=\frac{\frac{\sigma_{i}}{\varepsilon_{i}}+\sqrt{\left(\frac{\sigma_{i}}{\varepsilon_{i}}\right)^{2}+4 F_{i} \sigma_{i} \frac{\varepsilon_{i}-1}{\varepsilon_{i}}}}{2 F_{i}} .
$$

From this expression, it is straightforward to show that the number of firms $N$ in each industry declines with $F$. This implies that lowering $F_{i}$ reduces $L I_{i}$ or, equivalently, increases competition in industry $i$. After tedious algebra, it is also possible to show that increasing elasticity of substitution $\varepsilon_{i}$ reduces $L I_{i}$.

In turn, allocations of $T$ and $L$ can be solved using (10), (11) and market clearing conditions:

$$
\begin{aligned}
& N_{1} T_{1}+N_{2} T_{2}=T, \\
& N_{1} L_{1}+N_{2} L_{2}=L .
\end{aligned}
$$

These allocations are given by

$$
\begin{aligned}
N_{i} T_{i} & =\frac{1}{1+\frac{\gamma_{-i}}{\gamma_{i}} \frac{\sigma_{-i}}{\sigma i}\left(1-\frac{1}{e_{-i}}\right)\left(1-\frac{1}{e_{i}}\right)^{-1}} T \\
N_{i} L_{i} & =\frac{1}{1+\frac{1-\gamma_{-i}}{1-\gamma_{i}} \frac{\sigma_{-i}}{\sigma_{i}}\left(1-\frac{1}{e_{-i}}\right)\left(1-\frac{1}{e_{i}}\right)^{-1}} L .
\end{aligned}
$$

Let industries have equal shares $\left(\sigma_{i} \equiv \sigma\right)$, then increasing $T$ increases $N_{1} T_{1}$ more than $N_{2} T_{2}$. This result holds because industry 1 depends on telecommunication technologies more than industry $2\left(\gamma_{1}>\gamma_{2}\right)$. It is the central implication of our model and motivates our difference-in-differences strategy. What remains to answer is: how can the higher use of telecommunications in an industry affect competition in that industry?

We follow Leff (1984) and Jensen (2007) and assume that the higher use of telecommu- 
nications in an industry increases the amount of information flows in/about that industry. Further, we follow, for example, Freund and Weinhold (2004) and Jensen (2007) and assume that this generates cost-saving externality so that $F_{i}=F_{i}\left(N_{i} T_{i}\right)$ and $F_{i}^{\prime}<0$. This implies that $N_{1}$ increases more than $N_{2}$. Therefore, increasing $T$ increases competition more in the industry that depends more on telecommunication technologies (industry 1).

In an industry, firms might also use telecommunication technologies to increase product differentiation and reduce competition [i.e., $\varepsilon_{i}=\varepsilon_{i}\left(N_{i} T_{i}\right)$ and $\left.\varepsilon_{i}^{\prime}<0\right]$. In such a case, the effect of increasing $T$ on competitive pressure depends on the functional forms of $\varepsilon($. and $F($.$) ; therefore, a priori it can be ambiguous.$

Clearly, F can also be interpreted as operational fixed costs (e.g., management costs) since we assume that firms live for one period. These costs can include the costs of information flows within firms. Higher use of telecommunications can reduce the costs of information flows. This line of logic implies that $F$ would decline more in industry 1 than in industry 2 if $T$ increases since, given the number of firms, $T_{1}$ increases more with $T$ than $T_{2}$. Therefore, higher $T$ would facilitate higher competition in industry 1 than in industry 2 .

This model can be easily extended so that the firms live for more than one period and have operational fixed costs. In such a case, assuming free entry, the firms' discounted value of revenue streams net of variable costs will be equal to the sum of entry and (the discounted value of) operational fixed costs. The decline of any of these fixed costs will intensify competition. Therefore, as long as increasing $T$ reduces operational fixed costs and/or entry costs, increasing $T$ will increase competition.

Increasing $T$ may also increase the productivity of firms, $\lambda$. In this model, however, this would not affect $L I$ given that we have assumed perfectly flexible prices. Relaxing this assumption can give another mechanism that can generate a positive relation between $L I$ and $T$. 


\title{
C Online Appendix - Further Results
}

\author{
Alternative Measures for Telecom Dependence
}

Our main measure of dependence on telecommunication technologies is the share of expenditures on telecommunications out of total expenditures on intermediate inputs in US industries. Our results would be wrong if this measure fails to identify correctly the ranking of industries according to their dependence. For robustness checks we also use expenditures on telecommunications relative to output in US industries (the so-called "technical coefficients") and the coefficients of the inverse Leontief matrix of US industries as measures of telecom dependence.

We obtain the data for these measures from the input-output tables of the Bureau of Economic Analysis and average the measures over the 1997-2006 period. Table A7 offers rank correlations for all our measures of dependence on telecommunication technologies. Table A8 offers rank correlations for our main measures of telecom dependence and shares of expenditures on telecommunications in the industries in European countries in our sample.

Columns (1) and (2) in Table A11 offer the results where we use these dependence measures, while for competition and telecom diffusion we use our main measures. The estimated coefficients are again negative and significant, which reaffirms our main result.

It can also be argued that European countries tend to be somewhat behind the United States in terms of the use of ICT. For a robustness check, we also employ the share of expenditures on telecommunications in 1994 in the United States. ${ }^{18}$ Column (3) in Table A11 reports the results. The estimate of the coefficient is not different from our main result.

For a further robustness check, we also obtain industry-level data for the United Kingdom from the input-output tables from the OECD STAN database. Column (4)

\footnotetext{
${ }^{18}$ We could use any date prior to 1997 and after 1993. It turns out that as we go towards 1993, our results become more pronounced and significant. This may partly stem from the technological lag between European countries and the United States.
} 
in Table A11 offers the results where we use UK data for measuring dependence on telecommunication technologies. The estimated coefficient is smaller in absolute value than our main result $[-0.67(0.39)]$. However, it is not substantially smaller from the result for the measure identified from the OECD STAN database for the US, which is presented in column (3) of Table 2, [-1.65 (0.24)]. The former, in its turn, is quite close to the main result.

A reason behind such variation can be the higher noise in the UK data. For instance, the dependence measure identified from the data for the UK has lower rank correlations with the share of telecommunications expenditures in industries in the remainder of sample countries, compared to the measures identified from the data for the US (see Table A8).

We have further checked that all our results are qualitatively the same for these alternative measures of dependence.

\section{Alternative Measures for Competition and Industry Share}

We also calculate the price cost margin from firm-level data using the Amadeus database (PCMa) and employ it as a competition measure.

Table A9 reports correlations among all our competition measures. Table A10 reports correlations among the remaining industry level variables.

Column (5) in Table A11 reports the results for the price cost margin, which is derived from the Amadeus database. The estimate of the coefficient on the interaction term has the expected sign and is significant. It is considerably smaller, though, than our main result $[-0.55(0.26)]$. The predicted magnitude of the effect according to this estimate is also smaller, -0.004. However, relative to the mean of this measure, 0.09, the predicted magnitude is still comparably large, $5 \%$.

Further, we have checked that our results hold when we take the number of firms from the Amadeus database, which, in contrast to the OECD STAN database, does not have full coverage. ${ }^{19}$

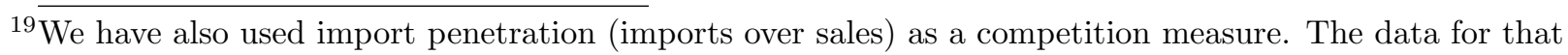
measure we have obtained from the OECD STAN database. The estimated coefficient is positive, though not significant at the $10 \%$ level, and is not reported. The positive coefficient is consistent with the rest
} 
Finally, we have checked that our results are not qualitatively different if instead of the share in sales we use the share in value-added.

\section{Alternative Estimators and Robustness to Outliers}

The competition measure PCM varies from 0 to 1 . We estimate the baseline specification (1) with Tobit and report the results in column (1) of Table A12. Further, in order to alleviate the influence of outliers, if any, we estimate the baseline specification using a quantile regression. We estimate it also on a sample that excludes the first and the last percentiles of the dependent variable, PCM. The results are reported in columns (2) and (3) of Table A12.

When appropriate, we have checked that all our results are qualitatively the same with these alternative estimators.

\section{Alternative Sample Restrictions: Is the UK different?}

The UK might be expected to be different from the remaining countries, in terms of the use of telecommunication technologies and its development level. Column (4) in Table A12 excludes the UK from the sample. The result is the same as our main result.

Alternative Sample Restrictions: Are the industries that use telecommunications the least any different?

Our main measure for identifying the industries that use telecommunication technologies the least is the interaction between the variables Industry Share and Telecom Dependence. In a country, we take those industries that have a value lower than the median in the country.

As a robustness check, we also take those industries in a country that have expenditures on telecommunications which are below the median in the country in 1995 . We obtain the data for this measure from the input-output tables from the OECD STAN database. of our estimates. Meanwhile, the estimate is not significant, perhaps because we have few data for that measure. 
We use the dependence measure identified from that database in the estimation for this group of industries since the OECD STAN database has a slightly different aggregation.

Column (5) of Table A12 reports the results. The estimate of the coefficient is very close to the result we have obtained using OECD STAN data for the dependence measure [column (3) of Table 2].

\section{Alternative Additional Variables/Interaction Terms}

In the main text, for additional country-level variables that might proxy entry costs, we use various measures to identify the ranking of industries according to the effect of these variables. It may also be argued that the ranking of the industries according to their dependence on telecommunication technologies corresponds to the ranking of industries according to the effect these additional country-level variables have on them. In columns (1)-(6) of Table A13, we include the interactions of Telecom Dependence with the respective variable together with our main interaction term one-by-one. Our main result, again, stays basically unchanged.

Our measure for the diffusion of telecommunication technologies may proxy regulation in the telecommunications industry. The latter, meanwhile, may proxy for country-level market regulation and entry costs, which matter more for industries that have a higher dependence on telecommunication technologies. Although according to column (3) of Table 3 and column (2) of Table A13 most likely this is not driving our results, we continue to explore such a possibility. From the OECD Stat database, we obtain a measure of telecommunications industry regulation and include in our baseline specification its interaction with Telecom Dependence. Column (7) of Table A13 offers the results. Our main result is unaffected. ${ }^{20}$

It could also be that countries with bigger shadow economies have a lower reporting of output and lower competition due to the adherence to rather informal agreements. ${ }^{21}$

${ }^{20}$ We have also checked that the changes in economy-wide product market regulation and telecommunications industry regulation (i.e., differences between 2006 and 1997 values) do not drive our results.

${ }^{21}$ For example, in our sample, PCM is $6 \%$ higher in countries where the shadow economy is more than the median compared to the remaining countries. 
Meanwhile, it could be that the industries that depend more on telecommunication technologies have a higher share in the shadow economy (e.g., services).

We take the measure of the size of the shadow economy and the data for it from Schneider (2002). This variable is expressed as a percentage of GNP and is averaged over the period 1999-2000. Column (1) of Table A14 includes the interaction of this variable with the measure of dependence on telecommunication technologies and reports the results. The estimate of the coefficient on our main interaction term is virtually not affected.

In the same vein, in the baseline specification (1), we have also included the interactions between GDP per capita and Telecom Dependence and Corruption Perception Index (CPI) and Telecom Dependence [see columns (2) and (3) in Table A14]. The main result is, again, virtually unaffected.

Finally, we add to our baseline specification the initial intensity of competition in an industry-country pair. Column (5) of Table A14 reports the results. The estimate of the coefficient on the interaction term stays negative which reaffirms our results. ${ }^{22}$

\section{Additional and Unreported Robustness Checks}

We have performed further robustness checks. For example, we have checked that our results stay unaffected if we:

- use the waiting list for main lines per capita as an instrumental variable (Röller and Waverman, 2001) together with our instrumental variables and separately;

- use the number of telecommunication employees per fixed lines and mobile phone subscribers as an additional instrumental variable;

- include in the baseline specification the principal components of the matrix of all additional variables which explain more than $90 \%$ of the variation in the data. We have used principal components due to the high collinearity among variables;

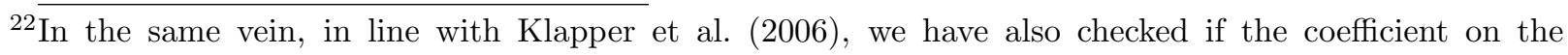
interaction term in the baseline specification is different for countries with a higher development level and lower corruption level. We have found no systematic and significant differences.
} 
- measure labour intensity with labour expenditures over output;

- add to the baseline specification the interactions of labour intensity and entry rate variables with the overall economic freedom index (in 1997) from the Heritage Foundation;

- measure financial development using private credit over GDP; and

- use other measures of human capital development from the Barro-Lee tables.

\section{The Effect of the Quality}

Recently, there have been extensive improvements in the quality of the telecommunications infrastructure. For example, the medium speed of information flow in telecommunication networks has increased from several kilobits per second at the beginning of the 90s to several megabits per second nowadays. While increasing the speed of information transmission, this progress can reduce the costs associated with information acquisition. Therefore, it seems reasonable to expect that in countries where the quality of the telecommunications infrastructure is higher, the impact of these technologies on competition is also higher.

To test this, we use as a measure of quality the ratio of fixed broadband subscribers to fixed-line telecommunications subscribers. ${ }^{23}$ We take the value of this ratio from 2000 since it has almost no variability before that. We also restrict the sample period to 2000-2006.

In the test, we divide the countries in our sample into two groups according to the level of the quality measure. Table A15 offers the results when we divide the countries into high and low levels of quality according to the median and 60th, 70th, 80th and 90th percentiles of our quality measure. These results suggest that in countries where the quality of telecommunications infrastructure is higher, the diffusion of these technologies has a larger positive effect on the intensity of competition in services and goods markets.

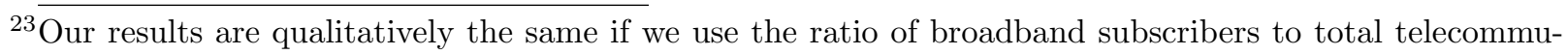
nication subscribers and the ratio of broadband subscribers to internet users.
} 
Summary Statistics and Correlations

Table A3: Summary Statistics

\begin{tabular}{lccccc}
\hline \hline Variable & Obs. & Mean & SD & Min. & Max. \\
\hline Country-level & & & & & \\
Broadband Diffusion Rate & 21 & 0.01 & 0.01 & 0.00 & 0.05 \\
CPI & 18 & 7.20 & 1.78 & 5.03 & 9.94 \\
GDPC & 21 & 16140.24 & 8999.58 & 3517.05 & 35325.19 \\
Shadow Economy & 20 & 0.20 & 0.05 & 0.10 & 0.29 \\
Telecom Regulation & 18 & 3.86 & 1.32 & 1.05 & 5.63 \\
Industry-level & & & & & \\
Telecom Dependence UK & 30 & 0.02 & 0.03 & 0.00 & 0.15 \\
Telecom Dependence (1994) & 47 & 0.01 & 0.01 & 0.00 & 0.06 \\
Telecom Dependence (Leontief) & 47 & 0.01 & 0.00 & 0.00 & 0.02 \\
Telecom Dependence (Output) & 47 & 0.01 & 0.01 & 0.00 & 0.03 \\
Industry-country-level & & & & & \\
PCMa & & & & & \\
PCM (1997) & 928 & 0.09 & 0.06 & 0.02 & 0.52 \\
\hline \hline
\end{tabular}

Note: This table reports statistics for the variables used for further robustness checks. All variables and data sources are defined in detail in Table A16 


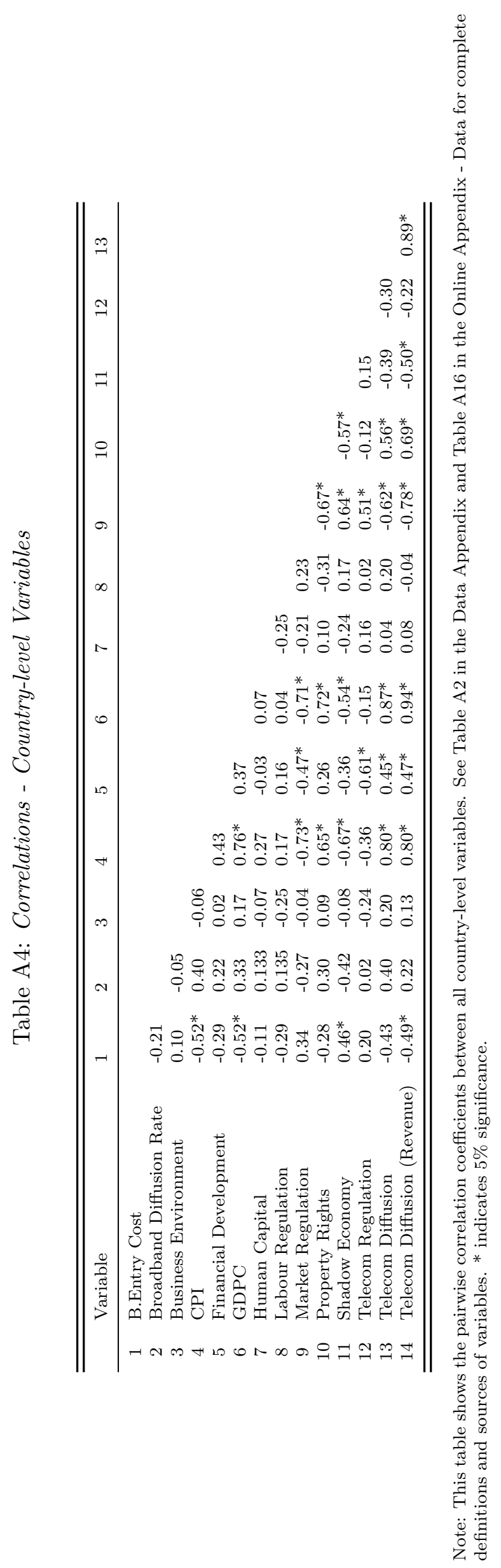


Table A5: The Country-level Values of Telecom Diffusion

\begin{tabular}{lcc}
\hline \hline Country & $\begin{array}{c}\text { Telecom } \\
\text { Diffusion }\end{array}$ & $\begin{array}{c}\text { Telecom } \\
\text { Diffusion (Revenue) }\end{array}$ \\
\hline Austria & 0.64 & 389.13 \\
Belgium & 0.56 & 377.41 \\
Czech Republic & 0.37 & 147.74 \\
Denmark & 0.91 & 573.82 \\
Estonia & 0.44 & 116.75 \\
Finland & 0.98 & 512.43 \\
France & 0.68 & 389.85 \\
Germany & 0.65 & 460.63 \\
Greece & 0.59 & 290.06 \\
Hungary & 0.37 & 156.29 \\
Ireland & 0.57 & 562.44 \\
Italy & 0.66 & 380.37 \\
Netherlands & 0.68 & 453.77 \\
Norway & 1.01 & 863.10 \\
Poland & 0.22 & 85.44 \\
Portugal & 0.55 & 351.83 \\
Slovakia & 0.30 & 105.28 \\
Slovenia & 0.40 & 135.86 \\
Spain & 0.51 & 316.32 \\
Sweden & 1.06 & 682.45 \\
UK & 0.70 & 653.39 \\
\hline \hline
\end{tabular}

Note: This table offers the country-level values of Telecom Diffusion measures. See Table A2 in the Data Appendix for definitions and sources of variables. 
Table A6: Telecom Dependence Measures

\begin{tabular}{|c|c|c|c|c|c|c|c|c|}
\hline \multirow[t]{2}{*}{ ISIC } & \multirow[t]{2}{*}{ Industry Name } & \multirow[t]{2}{*}{ Telecom Dependence [] } & \multicolumn{3}{|c|}{ ISIC } & \multirow[b]{2}{*}{ UK } & \multirow[b]{2}{*}{$(\mathrm{OECD})$} & \multirow[b]{2}{*}{$\mathrm{EU}$} \\
\hline & & & 1994 & & JP & & & \\
\hline 10 & Coal Mining & 0.0032 & 0.0032 & $10-14$ & 0.0146 & 0.0104 & 0.0076 & 0.0112 \\
\hline 11 & Oil and Gas Extraction & 0.0069 & 0.0070 & & & & & \\
\hline 13 & Mining of Metal Ores & 0.0022 & 0.0020 & & & & & \\
\hline 14 & Other Mining and Quarrying & 0.0064 & 0.0061 & & & & & \\
\hline 15 & Food Products and Beverages & 0.0020 & 0.0021 & $15-16$ & 0.0025 & 0.0103 & 0.0079 & 0.0060 \\
\hline 16 & Tobacco Products & 0.0004 & 0.0006 & & & & & \\
\hline 17 & Textiles & 0.0035 & 0.0027 & $17-19$ & 0.0072 & 0.0082 & 0.0066 & 0.0100 \\
\hline 18 & Wearing Apparel & 0.0053 & 0.0038 & & & & & \\
\hline 19 & Luggage, Handbags, Footwear & 0.0028 & 0.0016 & & & & & \\
\hline 20 & Wood, Except Furniture & 0.0046 & 0.0039 & 20 & 0.0028 & 0.0076 & 0.0058 & 0.0079 \\
\hline 21 & Pulp and Paper & 0.0031 & 0.0027 & $21-22$ & 0.0104 & 0.0131 & 0.0245 & 0.0245 \\
\hline 22 & Publishing, Printing & 0.0176 & 0.0146 & & & & & \\
\hline 23 & Coke and Petroleum Products & 0.0010 & 0.0010 & 23 & 0.0024 & 0.0037 & 0.0024 & 0.0031 \\
\hline 24 & Chemicals & 0.0026 & 0.0023 & 24 & 0.0084 & 0.0142 & 0.0098 & 0.0099 \\
\hline 25 & Rubber and Plastic Products & 0.0060 & 0.0053 & 25 & 0.0048 & 0.0099 & 0.0079 & 0.0102 \\
\hline 26 & Non-metallic Mineral Products & 0.0062 & 0.0054 & 26 & 0.0047 & 0.0131 & 0.0093 & 0.0107 \\
\hline 27 & Basic Metals & 0.0025 & 0.0022 & 27 & 0.0025 & 0.0062 & 0.0039 & 0.0055 \\
\hline 28 & Fabricated Metal Products & 0.0081 & 0.0071 & 28 & 0.0103 & 0.0096 & 0.0102 & 0.0107 \\
\hline 29 & Machinery and Equipment N.E.C. & 0.0058 & 0.0056 & 28 & 0.0063 & 0.0083 & 0.0145 & 0.0111 \\
\hline 30 & Office Machinery and Computers & 0.0039 & 0.0040 & 30 & 0.0042 & 0.0065 & 0.0142 & 0.0137 \\
\hline 31 & Electrical Machinery & 0.0040 & 0.0037 & 31 & 0.0052 & 0.0091 & 0.0091 & 0.0095 \\
\hline 32 & Communication Equipment & 0.0070 & 0.0079 & 32 & 0.0046 & 0.0068 & 0.0160 & 0.0116 \\
\hline 33 & Instruments, Watches and Clocks & 0.0080 & 0.0081 & 33 & 0.0072 & 0.0106 & 0.0182 & 0.0149 \\
\hline 34 & Motor Vehicles and Trailers & 0.0011 & 0.0010 & 34 & 0.0018 & 0.0051 & 0.0066 & 0.0054 \\
\hline 35 & Other Transport Equipment & 0.0034 & 0.0029 & 35 & 0.0037 & 0.0057 & 0.0086 & 0.0083 \\
\hline 36 & Furniture Manufacturing N.E.C. & 0.0100 & 0.0086 & $36-37$ & 0.0061 & 0.0082 & 0.0164 & 0.0099 \\
\hline 40 & Electricity, Gas, Hot Water & 0.0024 & 0.0022 & $40-41$ & 0.0090 & 0.0055 & 0.0074 & 0.0145 \\
\hline 41 & Distribution of Water & 0.0290 & 0.0250 & & & & & \\
\hline 45 & Construction & 0.0164 & 0.0138 & 45 & 0.0178 & 0.0085 & 0.0225 & 0.0083 \\
\hline 50 & Sale and Repair of Motor Vehicles & 0.0281 & 0.0234 & $50-52$ & 0.0660 & 0.0380 & 0.0480 & 0.0447 \\
\hline 51 & Wholesale Trade & 0.0264 & 0.0245 & & & & & \\
\hline 52 & Retail Trade & 0.0216 & 0.0194 & & & & & \\
\hline 55 & Hotels and Restaurants & 0.0164 & 0.0149 & 55 & 0.0248 & 0.0338 & 0.0305 & 0.0234 \\
\hline 60 & Land Transport & 0.0169 & 0.0149 & $60-63$ & 0.0210 & 0.0246 & 0.0302 & 0.0238 \\
\hline 61 & Water Transport & 0.0118 & 0.0105 & & & & & \\
\hline 62 & Air Transport & 0.0351 & 0.0321 & & & & & \\
\hline 63 & Supporting Transport Activities & 0.0246 & 0.0221 & & & & & \\
\hline 65 & Financial Intermediation & 0.0196 & 0.0205 & $65-67$ & 0.0586 & 0.1548 & 0.0344 & 0.0803 \\
\hline 66 & Insurance and Pension Funding & 0.0071 & 0.0074 & & & & & \\
\hline 67 & Activities Auxiliary to & 0.0577 & 0.0602 & & & & & \\
\hline & Financial Intermediation & & & & & & & \\
\hline 70 & Real Estate Activities & 0.0206 & 0.0182 & 70 & 0.0088 & 0.0298 & 0.0267 & 0.0207 \\
\hline 71 & Renting of Machinery, Equipment & 0.0228 & 0.0214 & 71 & 0.0115 & 0.0379 & 0.0405 & 0.0411 \\
\hline 72 & Computer and Related Activities & 0.0634 & 0.0618 & 72 & 0.0421 & 0.0337 & 0.0960 & 0.0766 \\
\hline 73 & Research and Development & 0.0185 & 0.0168 & 73 & 0.0654 & 0.0214 & 0.0672 & 0.0431 \\
\hline 74 & Other Business Activities & 0.0536 & 0.0507 & 74 & 0.0887 & 0.0488 & 0.0878 & 0.0512 \\
\hline 92 & Recreational, Cultural, and & 0.0179 & 0.0148 & & & & & \\
\hline 93 & $\begin{array}{l}\text { Sporting Activities } \\
\text { Other Service Activities }\end{array}$ & 0.0384 & 0.0323 & & & & & \\
\hline
\end{tabular}

Note: This table offers the values of telecom dependence measures for 2-digit ISIC industries. In the first two columns, this measure is computed from US data using input-output tables obtained from the Bureau of Economic Analysis (BEA). The first column offers the values of our main dependence measure. The last four columns offer the values of telecom dependence measures which we compute using data for Japan, the United Kingdom, the US, and European countries from our sample. These are computed using input-output tables obtained from the OECD STAN database and are averaged over the years 1995, 2000 and 2005. The measure computed using data from sample countries is averaged across these countries. There are differences between BEA and OECD measures because of the differences in the aggregation levels for the telecommunications industry. With BEA data we compute the dependence using ISIC 642 industry which is solely for the telecommunications industry. Meanwhile, OECD data does not permit such a disaggregation and we compute dependence measures using ISIC 64 industry which also includes post and courier activities. See Table A2 in the Data Appendix and Table A16 in the Online Appendix - Data for the definitions and data sources. 
Table A7: Rank Correlations - Telecom Dependence Measures

\begin{tabular}{lccccccc}
\hline \hline Telecom Dependence [] & EU & JP & UK & - & $(1994)$ & (Leontief) & (OECD) \\
\hline JP & 0.83 & & & & & & \\
UK & 0.78 & 0.80 & & & & & \\
- & 0.87 & 0.87 & 0.75 & & & & \\
(1994) & 0.89 & 0.86 & 0.74 & 0.99 & & & \\
(Leontief) & 0.65 & 0.56 & 0.52 & 0.78 & 0.79 & & \\
(OECD) & 0.85 & 0.81 & 0.80 & 0.88 & 0.89 & 0.80 & \\
(Output) & 0.83 & 0.84 & 0.69 & 0.97 & 0.97 & 0.86 & 0.87 \\
\hline \hline
\end{tabular}

Note: This table offers the pairwise Spearman's rank correlation coefficients between the measures of dependence on telecommunication technologies. See Table A2 in the Data Appendix and Table A16 in the Online Appendix - Data for the definitions and data sources. All correlation coefficients are significant at the $1 \%$ level.

Table A8: Rank Correlations - Telecom Dependence Measures and Shares of Expenditures on Telecommunications in Sample Industry-Country Pairs

\begin{tabular}{lccccc}
\hline \hline Telecom Dependence [] & EU & JP & UK & - & $($ OECD $)$ \\
\hline JP & 0.83 & & & & \\
UK & 0.78 & 0.80 & & & \\
(OECD) & 0.87 & 0.87 & 0.75 & & \\
Austria & 0.85 & 0.81 & 0.80 & 0.88 & \\
Belgium & 0.83 & 0.72 & 0.71 & 0.68 & 0.78 \\
Czech Republic & 0.91 & 0.76 & 0.61 & 0.81 & 0.82 \\
Denmark & 0.89 & 0.85 & 0.83 & 0.91 & 0.87 \\
Estonia & 0.85 & 0.81 & 0.77 & 0.81 & 0.80 \\
Finland & 0.77 & 0.68 & 0.62 & 0.75 & 0.77 \\
France & 0.82 & 0.75 & 0.69 & 0.75 & 0.66 \\
Germany & 0.83 & 0.84 & 0.74 & 0.85 & 0.80 \\
Greece & 0.90 & 0.75 & 0.67 & 0.74 & 0.76 \\
Hungary & 0.93 & 0.74 & 0.68 & 0.85 & 0.81 \\
Ireland & 0.82 & 0.87 & 0.75 & 0.90 & 0.81 \\
Italy & 0.61 & 0.57 & 0.56 & 0.58 & 0.39 \\
Netherlands & 0.84 & 0.77 & 0.63 & 0.84 & 0.78 \\
Norway & 0.83 & 0.75 & 0.78 & 0.83 & 0.82 \\
Poland & 0.71 & 0.57 & 0.50 & 0.63 & 0.58 \\
Portugal & 0.83 & 0.77 & 0.73 & 0.78 & 0.85 \\
Slovakia & 0.88 & 0.89 & 0.85 & 0.87 & 0.80 \\
Slovenia & 0.91 & 0.80 & 0.71 & 0.85 & 0.87 \\
Spain & 0.91 & 0.78 & 0.70 & 0.86 & 0.84 \\
Sweden & 0.88 & 0.77 & 0.76 & 0.72 & 0.73 \\
\hline \hline
\end{tabular}

Note: This table offers the pairwise Spearman's rank correlation coefficients between the measures of dependence on telecommunication technologies and the share of telecommunications expenditures out of total expenditures on intermediate inputs in industries in European countries. See Table A2 in the Data Appendix and Table A16 in the Online Appendix Data for the definitions and sources of variables. All correlation coefficients are significant at the $1 \%$ level.

Table A9: Correlations - Competition Measures

\begin{tabular}{lllllll}
\hline \hline & & 1 & 2 & 3 & 4 & 5 \\
\hline 1 & $\mathrm{HI}$ & & & & & \\
2 & $\operatorname{logN}$ & $-0.66^{*}$ & & & & \\
3 & $\mathrm{MS}$ & $0.88^{*}$ & $-0.74^{*}$ & & & \\
4 & $\mathrm{PCM}$ & -0.00 & $0.16^{*}$ & -0.06 & & \\
5 & $\mathrm{PCMa}$ & $0.16^{*}$ & $-0.19^{*}$ & $0.16^{*}$ & $0.49^{*}$ & \\
6 & $\mathrm{PE}$ & $-0.24^{*}$ & $0.29^{*}$ & $-0.29^{*}$ & $0.27^{*}$ & $0.31^{*}$ \\
\hline \hline
\end{tabular}

Note: This table offers the pairwise correlation coefficients between competition measures. See Table A2 in the Data Appendix and Table A16 in the Online Appendix - Data for the definitions and sources of variables. * indicates the 5\% level of significance. 
Table A10: Correlations - Industry-level Variables

\begin{tabular}{llllllll}
\hline \hline & 1 & 2 & 3 & 4 & 5 & 6 \\
\hline 1 & Entry Rate & & & & & & \\
2 & Ext. Fin. Dependence & 0.05 & & & & & \\
3 & Growth Potential & 0.20 & $0.43^{*}$ & & & & \\
4 & Growth Potential EU & 0.01 & $0.31^{*}$ & $0.44^{*}$ & & & \\
5 & Labour Intensity & 0.29 & -0.03 & 0.36 & -0.39 & & \\
6 & R\&D Intensity & $0.42^{*}$ & $0.60^{*}$ & $0.44^{*}$ & 0.22 & -0.10 & \\
7 & Telecom Dependence & $0.35^{*}$ & 0.11 & $0.52^{*}$ & 0.07 & 0.31 & 0.14 \\
\hline \hline
\end{tabular}

Note: This table offers the pairwise correlation coefficients between industry-level variables, excluding the competition measures. See Table A2 in the Data Appendix and Table A16 in the Online Appendix - Data for complete definitions and sources of variables. ${ }^{*}$ indicates the $5 \%$ level of significance.

\section{Regression Results}

Table A11: Alternative Measures of Telecom Dependence and Competition

\begin{tabular}{lccccc}
\hline \hline & $(1)$ & $(2)$ & $(3)$ & $(4)$ & $(5)$ \\
& $($ Output $)$ & $($ Leontief $)$ & $(1994)$ & UK & PCMa \\
\cline { 2 - 6 } & $-7.22^{* * *}$ & $\left.\begin{array}{c}-11.12^{* * *} \\
\text { Telecom Dependence }\end{array}\right]$ & $-2.70^{* * *}$ & $-0.67^{* *}$ & \\
$\times$ Telecom Diffusion & $(1.01)$ & $(1.67)$ & $(0.38)$ & $(0.30)$ & \\
Telecom Dependence & & & & & $-0.55^{* *}$ \\
$\times$ Telecom Diffusion & & & & & $(0.26)$ \\
Industry Share & $0.68^{* * *}$ & $0.70^{* * *}$ & $0.69^{* * *}$ & $0.79^{* *}$ & $0.38^{* * *}$ \\
& $(0.26)$ & $(0.27)$ & $(0.27)$ & $(0.32)$ & $(0.10)$ \\
\hline Observations & 902 & 902 & 902 & 618 & 876 \\
R2 & 0.72 & 0.72 & 0.72 & 0.74 & 0.49 \\
\hline \hline
\end{tabular}

Note: This table reports the results from the baseline specification (1) for various measures of telecom dependence and intensity of competition. In columns (1)-(4), the dependent variable is the competition measure PCM, which we calculate using OECD STAN data. In these columns, we vary the dependence measure. In column (1), the dependence measure is the ratio of expenditures on telecommunications to output, Telecom Dependence (Output). In column (2), the dependence measure is US industries' coefficients of the inverse Leontief matrix, Telecom Dependence (Leontief). In column (3), the dependence measure is the share of expenditures on telecommunications out of expenditures on intermediate inputs in US industries in 1994, Telecom Dependence (1994). In column (4), the telecom dependence measure is identified from UK industries. In column (5), the dependent variable is the competition measure PCMa, which we calculate using Amadeus data. See Table A2 in the Data Appendix and Table A16 in the Online Appendix - Data for the definitions and sources of variables. All regressions include industry and country dummies and use the least squares estimation method. Robust (clustered) standard errors are in parentheses. ${ }^{* * *}$ indicates significance at the $1 \%$ level, ${ }^{* *}$ at the $5 \%$ level and ${ }^{*}$ at the $10 \%$ level. 
Table A12: Alternative Estimators and Various Sample Restrictions

\begin{tabular}{|c|c|c|c|c|c|}
\hline & $\begin{array}{c}(1) \\
\text { Tobit }\end{array}$ & $\begin{array}{c}(2) \\
\text { Quantile }\end{array}$ & $\begin{array}{c}(3) \\
\text { OLS w/o } \\
1 \& 100 \%\end{array}$ & $\begin{array}{c}\text { (4) } \\
\text { W/o UK }\end{array}$ & $\begin{array}{c}(5) \\
\text { Least Telecom } \\
\text { User } \\
\text { (Expenditure) }\end{array}$ \\
\hline $\begin{array}{l}\text { Telecom Dependence } \\
\times \text { Telecom Diffusion }\end{array}$ & $\begin{array}{c}-2.66^{* * *} \\
(0.35)\end{array}$ & $\begin{array}{c}-2.27^{* * *} \\
(0.42)\end{array}$ & $\begin{array}{c}-2.56 * * * \\
(0.36)\end{array}$ & $\begin{array}{c}-2.67 * * * \\
(0.37)\end{array}$ & \\
\hline $\begin{array}{l}\text { Telecom Dependence (OECD) } \\
\times \text { Telecom Diffusion }\end{array}$ & & & & & $\begin{array}{l}-1.16^{* *} \\
(0.50)\end{array}$ \\
\hline Chow test (p-value) & & & & 0.80 & 0.03 \\
\hline Industry Share & $\begin{array}{c}0.69 * * * \\
(0.25)\end{array}$ & $\begin{array}{l}0.43^{*} \\
(0.25)\end{array}$ & $\begin{array}{c}0.46^{* *} \\
(0.22)\end{array}$ & $\begin{array}{c}0.69 * * \\
(0.28)\end{array}$ & $\begin{array}{r}0.26 \\
(0.54)\end{array}$ \\
\hline Observations & 902 & 902 & 884 & 861 & 307 \\
\hline $\mathrm{R} 2$ & - & 0.50 & 0.68 & 0.72 & 0.70 \\
\hline
\end{tabular}

Note: This table reports the results from the baseline specification for alternative estimators and various sample restrictions. The dependent variable is the competition measure PCM. Column (1) reports the estimates from the Tobit regression with censoring at 0 and 1 , and column (2) reports the estimates from a quantile regression. Columns (3)-(5) use the least squares estimation method. Column (3) reports the results for a sample that excludes the first and last percentiles of PCM. In column (4), the United Kingdom is excluded from the sample. Column (5) excludes the industries in a country that have higher-than-median expenditures on telecommunications in the country in 1995. For samples in columns (4)-(5), we perform Chow tests for the coefficients on the interaction terms. The p-values of corresponding t-statistics are reported in the row Chow test. See Table A2 in Data Appendix and Table A16 in the Online Appendix - Data for the definitions and sources of variables. Pseudo R2 is reported for the quantile regression. All regressions include industry and country dummies. Robust (clustered) standard errors are in parentheses. ${ }^{* * *}$ indicates significance at the $1 \%$ level, ${ }^{* *}$ at the $5 \%$ level and ${ }^{*}$ at the $10 \%$ level.

Table A13: Specification Check - Additional Variables

\begin{tabular}{|c|c|c|c|c|c|c|c|}
\hline & $\begin{array}{l}(1) \\
\text { B.Entry } \\
\text { Cost }\end{array}$ & $\begin{array}{c}(2) \\
\text { Market } \\
\text { Regulation }\end{array}$ & $\begin{array}{c}\text { (3) } \\
\text { Financial } \\
\text { Development }\end{array}$ & $\begin{array}{c}(4) \\
\text { Labour } \\
\text { Regulation }\end{array}$ & $\begin{array}{l}\text { (5) } \\
\text { Property } \\
\text { Rights }\end{array}$ & $\begin{array}{c}(6) \\
\text { Human } \\
\text { Capital }\end{array}$ & $\begin{array}{c}(7) \\
\text { Telecom } \\
\text { Regulation }\end{array}$ \\
\hline $\begin{array}{l}\text { Telecom Dependence } \\
\times \text { Telecom Diffusion }\end{array}$ & $\begin{array}{c}-2.49^{* * *} \\
(0.40)\end{array}$ & $\begin{array}{c}-3.17^{* * *} \\
(0.71)\end{array}$ & $\begin{array}{c}-2.55^{* * *} \\
(0.41)\end{array}$ & $\begin{array}{c}-2.68^{* * *} \\
(0.37)\end{array}$ & $\begin{array}{c}-3.50^{* * *} \\
(0.47)\end{array}$ & $\begin{array}{c}-2.69^{* * * *} \\
(0.36)\end{array}$ & $\begin{array}{c}-3.34 * * * \\
(0.45)\end{array}$ \\
\hline $\begin{array}{l}\text { Telecom Dependence } \\
\times \text { B.Entry Cost }\end{array}$ & $\begin{array}{l}1.07 \\
(1.07)\end{array}$ & & & & & & \\
\hline $\begin{array}{l}\text { Telecom Dependence } \\
\times \text { Market Regulation }\end{array}$ & & $\begin{array}{c}0.11 \\
(0.47)\end{array}$ & & & & & \\
\hline $\begin{array}{l}\text { Telecom Dependence } \\
\times \text { Financial Development }\end{array}$ & & & $\begin{array}{l}-0.43 \\
(0.76)\end{array}$ & & & & \\
\hline $\begin{array}{l}\text { Telecom Dependence } \\
\times \text { Labour Regulation }\end{array}$ & & & & $\begin{array}{l}-0.19 \\
(1.34)\end{array}$ & & & \\
\hline $\begin{array}{l}\text { Telecom Dependence } \\
\times \text { Property Rights }\end{array}$ & & & & & $\begin{array}{c}4.36^{* * *} \\
(1.47)\end{array}$ & & \\
\hline $\begin{array}{l}\text { Telecom Dependence } \\
\times \text { Human Capital }\end{array}$ & & & & & & $\begin{array}{l}-2.01 \\
(1.28)\end{array}$ & \\
\hline $\begin{array}{l}\text { Telecom Dependence } \\
\times \text { Telecom Regulation }\end{array}$ & & & & & & & $\begin{array}{l}-0.05 \\
(0.13)\end{array}$ \\
\hline Industry Share & $\begin{array}{c}0.72^{* * *} \\
(0.26)\end{array}$ & $\begin{array}{c}0.80^{* * *} \\
(0.28)\end{array}$ & $\begin{array}{c}0.69^{* * *} \\
(0.27)\end{array}$ & $\begin{array}{c}0.72^{* * *} \\
(0.26)\end{array}$ & $\begin{array}{c}0.67^{* *} \\
(0.27)\end{array}$ & $\begin{array}{c}0.69^{* * *} \\
(0.26)\end{array}$ & $\begin{array}{c}0.79^{* * *} \\
(0.27)\end{array}$ \\
\hline Observations & 857 & 769 & 902 & 857 & 902 & 902 & 769 \\
\hline $\mathrm{R} 2$ & 0.71 & 0.70 & 0.72 & 0.71 & 0.72 & 0.72 & 0.70 \\
\hline
\end{tabular}

Note: This table reports the results from specifications that augment the baseline with additional interaction terms. The dependent variable is the competition measure PCM. See Table A2 in Data Appendix and Table A16 in Online Appendix - Data for the definitions and sources of variables. All regressions include industry and country dummies and use the least squares estimation method. Robust (clustered) standard errors are in parentheses. $* * *$ indicates significance at the $1 \%$ level, ${ }^{* *}$ at the $5 \%$ level and ${ }^{*}$ at the $10 \%$ level. 
Table A14: Specification Check - Additional Variables

\begin{tabular}{lcccc}
\hline \hline & $(1)$ & $(2)$ & $(3)$ & $(4)$ \\
& $\begin{array}{c}\text { Shadow } \\
\text { Economy }\end{array}$ & GDPC & CPI & $\begin{array}{c}\text { PCM } \\
(1997)\end{array}$ \\
\cline { 2 - 5 } & & & $-0.70^{* * *}$ \\
Telecom Dependence & $-2.64^{* * *}$ & $-2.56^{* * *}$ & $-3.52^{* * *}$ & $-13)$ \\
$\times$ Telecom Diffusion & $(0.43)$ & $(0.77)$ & $(0.73)$ & $(0.27)$ \\
Telecom Dependence & 0.86 & & & \\
$\times$ Shadow Economy & $(3.73)$ & & & \\
Telecom Dependence & & -0.06 & & \\
$\times$ GDPC & & $(0.44)$ & & \\
Telecom Dependence & & & 0.06 & \\
$\times$ CPI & & & $(0.17)$ & \\
PCM (1997) & & & & $0.73^{* * *}$ \\
& $0.72^{* * *}$ & $0.69^{* *}$ & $0.79 * * *$ & $0.03)$ \\
Industry Share & $(0.26)$ & $(0.27)$ & $(0.27)$ & $(0.08)$ \\
\hline Observations & 857 & 902 & 769 & 840 \\
R2 & 0.71 & 0.72 & 0.70 & 0.93 \\
\hline \hline
\end{tabular}

Note: This table reports the results from specifications that augment the baseline with additional variables/interaction terms. The dependent variable is the competition measure PCM. See Table A2 in the Data Appendix and Table A16 in the Online Appendix - Data for the definitions and sources of variables. All regressions include industry and country dummies and use the least squares estimation method. Robust (clustered) standard errors are in parentheses. $* * *$ indicates significance at the $1 \%$ level, $* *$ at the $5 \%$ level and $*$ at the $10 \%$ level.

Table A15: High versus Low Quality - Broadband Diffusion Rate

\begin{tabular}{lccccc}
\hline \hline & $(1)$ & $(2)$ & $(3)$ & $(4)$ & $(5)$ \\
& 50 th perc. & 60 th perc. & 70 th perc. & 80th perc. & 90th perc. \\
\cline { 2 - 6 } Telecom Dependence & $-2.23^{* * *}$ & $-2.22^{* * *}$ & $-2.66^{* * *}$ & $-2.99^{* * *}$ & $-2.94^{* * *}$ \\
$\times$ Telecom Subscribers & $(0.68)$ & $(0.68)$ & $(0.63)$ & $(0.58)$ & $(0.57)$ \\
Telecom Dependence & $-3.75^{* * *}$ & $-3.81^{* * *}$ & $-2.77^{* *}$ & -1.92 & $-3.30^{*}$ \\
$\times$ Telecom Subscribers & $(1.38)$ & $(1.37)$ & $(1.31)$ & $(1.56)$ & $(1.90)$ \\
× High Broadband & & & & & \\
Industry Share & $0.71^{* *}$ & $0.71^{* *}$ & $0.72^{* *}$ & $0.72^{* *}$ & $0.72^{* *}$ \\
& $(0.29)$ & $(0.29)$ & $(0.29)$ & $(0.29)$ & $(0.29)$ \\
\hline Observations & 900 & 900 & 900 & 900 & 900 \\
R2 & 0.71 & 0.71 & 0.71 & 0.71 & 0.71 \\
\hline \hline
\end{tabular}

Note: This table reports the results from specifications that augment the baseline with an additional interaction term. The dependent variable is PCM and, together with the measure of telecom dependence, it is averaged over the period 2000-2006. Industry Share and Telecom Diffusion variables are from 2000. In column (1), variable High Broadband is equal to one for countries where Broadband Diffusion Rate is higher than the median and zero otherwise. In columns (2)-(5), High Broadband is equal to one in countries where Broadband Diffusion Rate is greater than the 60th, 70th, 80th and 90th percentiles of its between-countries distribution correspondingly, and zero otherwise. See Table A2 in the Data Appendix and Table A16 in the Online Appendix - Data for complete definitions and sources of variables. All regressions include industry and country dummies and use the least squares estimation method. Robust (clustered) standard errors are in parentheses. ${ }^{* * *}$ indicates significance at the $1 \%$ level, ${ }^{* *}$ at the $5 \%$ level and ${ }^{*}$ at the $10 \%$ level. 


\section{Online Appendix - Data}

Table A16: Definitions and Sources of Additional Variables

\begin{tabular}{|c|c|c|}
\hline \multicolumn{2}{|c|}{ Variable Name } & Definition and Source \\
\hline \multicolumn{3}{|c|}{ Country-level Variables } \\
\hline $\begin{array}{l}\text { Broadband } \\
\text { Rate }\end{array}$ & Diffusion & $\begin{array}{l}\text { Fixed broadband internet subscribers per fixed-line telecommunication } \\
\text { subscribers. The data are for } 2000 \text {. Source: Authors' calculations using } \\
\text { data from ITU and GMID. }\end{array}$ \\
\hline \multicolumn{2}{|l|}{ CPI } & $\begin{array}{l}\text { Corruption perception index in 1997. Source: Transparency Interna- } \\
\text { tional. }\end{array}$ \\
\hline \multicolumn{2}{|l|}{ GDPC } & GDP per capita (in 2000 US\$) in 1997. Source: WDI. \\
\hline \multicolumn{2}{|c|}{ Shadow Economy } & $\begin{array}{l}\text { The size of the informal economy as the share of GNP, averaged over the } \\
\text { period 1999-2000. Source: Schneider (2002). }\end{array}$ \\
\hline \multicolumn{2}{|c|}{ Telecom Regulation } & $\begin{array}{l}\text { Telecommunications industry regulation indicator in 1997. It takes into } \\
\text { account public control, entry and market structure. Source: OECD Stat. }\end{array}$ \\
\hline \multicolumn{3}{|c|}{ Industry-level Variables } \\
\hline \multicolumn{2}{|c|}{ Telecom Dependence UK } & $\begin{array}{l}\text { The share of (real) expenditures on telecommunications out of expendi- } \\
\text { tures on intermediate inputs in UK industries, averaged over the years } \\
1995,2000 \text { and } 2005 \text {. Source: Authors' calculations using data from } \\
\text { OECD STAN, I-O tables. }\end{array}$ \\
\hline $\begin{array}{l}\text { Telecom } \\
(1994)\end{array}$ & Dependence & $\begin{array}{l}\text { The share of (real) expenditures on telecommunications out of expendi- } \\
\text { tures on intermediate inputs in US industries in 1994. Source: Authors' } \\
\text { calculations using data from BEA, I-O tables. }\end{array}$ \\
\hline $\begin{array}{l}\text { Telecom } \\
\text { (Leontief) }\end{array}$ & Dependence & $\begin{array}{l}\text { The coefficients of the inverse Leontief matrix of US industries averaged } \\
\text { over the period 1997-2006. Source: Authors' calculations using data from } \\
\text { BEA, I-O tables. }\end{array}$ \\
\hline $\begin{array}{l}\text { Telecom } \\
\text { (Output) }\end{array}$ & Dependence & $\begin{array}{l}\text { The ratio of (real) expenditures on telecommunications to output in US } \\
\text { industries, averaged over the period 1997-2006. Source: Authors' calcu- } \\
\text { lations using data from BEA, I-O tables. }\end{array}$ \\
\hline \multicolumn{3}{|c|}{ Industry-country-level Variables } \\
\hline \multicolumn{2}{|l|}{ PCMa } & $\begin{array}{l}\text { Price cost margin is defined as the weighted average of firm-level price } \\
\text { cost margins computed as operational profit over operational revenue } \\
\text { within an industry, averaged over the period 1997-2006. Source: Authors' } \\
\text { calculations using data from Amadeus. }\end{array}$ \\
\hline \multicolumn{2}{|l|}{ PCM (1997) } & $\begin{array}{l}\text { PCM in 1997. Source: Authors' calculations using data from OECD } \\
\text { STAN. }\end{array}$ \\
\hline
\end{tabular}




\begin{tabular}{ll}
\hline Variable Name & Definition and Source \\
\hline & \\
Least Telecom Users (Ex- & Dummy variable that takes value 1 for an industry-country pair if ex- \\
penditure) & penditures on telecommunications are below the median in 1995 in the \\
& country, and zero otherwise. Source: Authors' calculations using data \\
& from OECD STAN and BEA. \\
\hline \hline
\end{tabular}

\section{E Online Appendix - Data Cleaning}

The Amadeus database is a product of the Bureau van Dijk. It consists of full and standardised information from balance sheets and profit/loss account items, identification information and the industry codes of European firms.

Amadeus has a specific feature regarding the exclusion of firms from the database. If a firm exits or stops reporting its financial data, Amadeus keeps this firm four years and then excludes it from the database. For example, in the 2010 edition of Amadeus, the data for 2006 do not include firms that exited in 2006 or before. For our analysis, we need to have as full a dataset as possible in order to obtain competition measures that better approximate the real intensity of competition. Therefore, we combine and use several Amadeus editions: March 2011, May 2010 and June 2007 downloaded from WRDS, and August 2003 and October 2001 DVD updates from Bureau van Dijk.

From the Amadeus database, we take operational revenues (for computing the Herfindahl index and the market share of the four largest firms), operational profits (for computing the PCM), and the industry codes of the firms. We transform all industry codes into ISIC rev. 3.1. We perform basic data cleaning in order to reduce potential selection bias and measurement errors by:

- dropping the firms that do not report operational revenue or total assets and firms that report their data in consolidated statements;

- imputing the missing values of key variables using linear interpolation across years. This helps to restore possibly erroneously missing values;

- dropping the industries which have less than four firms in a given year; 
- defining severe outliers as the first and the last percentiles of relative yearly changes in operational revenue and total assets for each country and the 2-digit industry code. If an outlier is at the beginning or at the end of the time period for a firm, then only the first or last observation is dropped. If an outlier is in the middle of the time period, the whole firm is dropped; and

- excluding observations with PCM below 0 and above 1 while computing the PCM. 